Prepared for the U.S. Department of Energy under Contract DE-AC05-76RL01830

\title{
Building Energy Audit Report for Pearl Harbor, $\mathrm{HI}$
}

\author{
DR Brown \\ DR Dixon
}

WD Chvála, Jr.

MI De La Rosa

September 2010

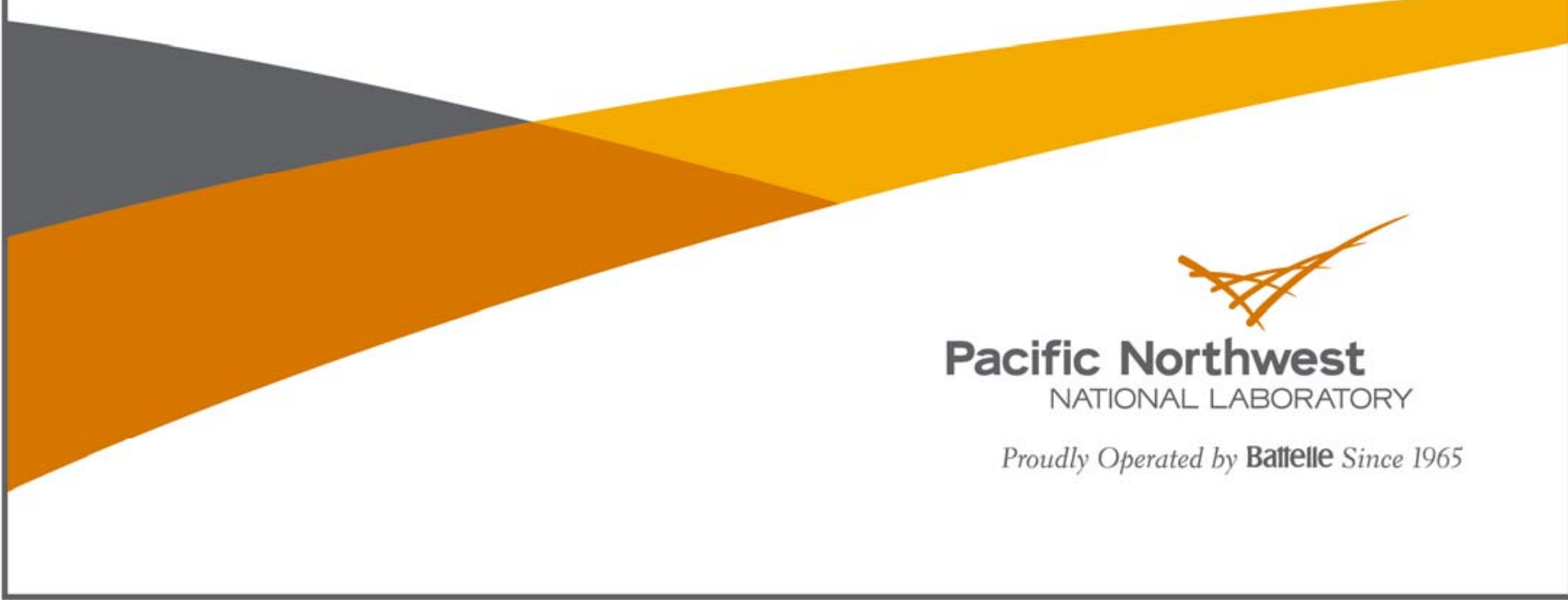




\title{
DISCLAIMER
}

This report was prepared as an account of work sponsored by an agency of the United States Government. Neither the United States Government nor any agency thereof, nor Battelle Memorial Institute, nor any of their employees, makes any warranty, express or implied, or assumes any legal liability or responsibility for the accuracy, completeness, or usefulness of any information, apparatus, product, or process disclosed, or represents that its use would not infringe privately owned rights. Reference herein to any specific commercial product, process, or service by trade name, trademark, manufacturer, or otherwise does not necessarily constitute or imply its endorsement, recommendation, or favoring by the United States Government or any agency thereof, or Battelle Memorial Institute. The views and opinions of authors expressed herein do not necessarily state or reflect those of the United States Government or any agency thereof.

\author{
PACIFIC NORTHWEST NATIONAL LABORATORY \\ operated by \\ BATTELLE \\ for the \\ UNITED STATES DEPARTMENT OF ENERGY \\ under Contract DE-AC05-76RL01830
}

Printed in the United States of America
Available to DOE and DOE contractors from the Office of Scientific and Technical Information,
P.O. Box 62, Oak Ridge, TN 37831-0062;
ph: (865) 576-8401
fax: (865) 576-5728
email: reports@adonis.osti.gov

\author{
Available to the public from the National Technical Information Service, \\ U.S. Department of Commerce, 5285 Port Royal Rd., Springfield, VA 22161 \\ ph: (800) 553-6847 \\ fax: (703) 605-6900 \\ email: orders@ntis.fedworld.gov \\ online ordering: http://www.ntis.gov/ordering.htm
}

This document was printed on recycled paper. 
PNNL-19678

\title{
Building Energy Audit Report for Pearl Harbor, HI
}

\author{
DR Brown DR Dixon \\ WD Chvála, Jr. \\ MI De La Rosa
}

September 2010

Prepared for

U.S. Department of Energy

Federal Energy Management Program

under Contract DE-AC05-76RL01830

Pacific Northwest National Laboratory

Richland, Washington 99352 



\section{Executive Summary}

An assessment of energy efficiency opportunities at Pearl Harbor, HI was performed by a team of engineers from Pacific Northwest National Laboratory (PNNL) under contract to the Department of Energy/Federal Energy Management Program (FEMP). The effort used the Facility Energy Decision System (FEDS) model to determine how energy is consumed at selected Pearl Harbor buildings, identify cost-effective energy retrofit measures, and calculate the potential energy and cost savings.

A team of engineers from PNNL visited Pearl Harbor January 19-29, 2010 to collect data for the FEDS assessment. During this visit, PNNL engineers collected energy-related information and data from six buildings selected by Pearl Harbor personnel for input into the FEDS model.

The economic results presented in this report are based on the use of two different sources of capital funds to implement the energy projects; appropriated funds (25-year project life and 3\% real discount rate), and alternative financing (e.g., Energy Savings Performance Contract [ESPC]). The alternative financing economic input assumptions (10-year project life and 10\% real discount rate) are for generic ESPC financing to illustrate the differences that the source of capital makes on the technology choices. The results are only based on direct construction costs, i.e., they do not include allowances for design and construction management (SIOH) costs. The FEDS software is capable of performing the comprehensive assessment using other sources of capital (e.g., utility financing) with their distinct economic inputs as well as adjusting the cost estimates to include additional items such as design, $\mathrm{SIOH}$, and contingency. Thus, the site is encouraged to re-run the FEDS software using site-specific alternative financing options and cost estimating assumptions, and then reassess the results.

This report documents the findings of the FEDS assessment and model results for appropriated funds and alternative financing sources of capital for the projects. A complete list of the 72 costeffective energy- and cost-reducing retrofit measures is included in Appendix B-1 for projects funded using the appropriated funding source of capital. The complete list of 38 cost-effective energy- and cost-reducing retrofit measures is included in Appendix B-2 for projects funded using the alternative financing source of capital.

Table ES.1 summarizes the results of the energy assessment by retrofit category for the appropriated fund source of capital. Table ES.2 summarizes the results of the energy assessment by retrofit category for alternative financing source of capital.

For the appropriated funds source of capital in Table ES.1, Pearl Harbor can save 13,704 MMBtu/year and \$663,410/year if all 72 cost-effective retrofits are implemented. The results change significantly if alternative financing is pursued. For the alternative financing source of capital shown in Table ES.2, Pearl Harbor can save 9,446 MMBtu/year and \$374,929/year if all 38 cost-effective retrofits are implemented. 
Table ES.1. Summary of Potential Energy and Cost Savings for Pearl Harbor Using the Appropriated Funds Source of Capital

\begin{tabular}{|l|c|r|r|r|r|c|}
\hline $\begin{array}{c}\text { Retrofit } \\
\text { Category }\end{array}$ & $\begin{array}{c}\text { Energy Savings } \\
\text { (MMBtu/yr) }\end{array}$ & $\begin{array}{c}\text { 1st Year } \\
\text { Savings } \\
\mathbf{( \$ / y r )}\end{array}$ & $\begin{array}{c}\text { Installed } \\
\text { Cost (\$) }\end{array}$ & $\begin{array}{c}\text { Net Present } \\
\text { Value (\$) }\end{array}$ & \multicolumn{1}{c|}{ SIR } & $\begin{array}{c}\text { Simple } \\
\text { Payback } \\
\text { (yr) }\end{array}$ \\
\hline Envelope & 2,158 & 76,742 & 413,561 & 894,072 & 3.2 & 5.4 \\
\hline Cooling & 3,893 & 197,942 & $1,254,765$ & $1,023,281$ & 1.8 & 6.3 \\
\hline Hot Water & 447 & 21,551 & 26,796 & 81,554 & 4.0 & 1.2 \\
\hline Lighting & 7,206 & 367,175 & $1,729,252$ & $4,413,720$ & 3.6 & 4.7 \\
\hline Total & $\mathbf{1 3 , 7 0 4}$ & $\mathbf{6 6 3 , 4 1 0}$ & $\mathbf{3 , 4 2 4 , 3 7 4}$ & $\mathbf{6 , 4 1 2 , 6 2 7}$ & $\mathbf{2 . 9}$ & $\mathbf{5 . 2}$ \\
\hline
\end{tabular}

Table ES.2. Summary of Potential Energy and Cost Savings for Pearl Harbor Using the Alternative Financing Source of Capital

\begin{tabular}{|l|c|r|r|r|r|c|}
\hline $\begin{array}{c}\text { Retrofit } \\
\text { Category }\end{array}$ & $\begin{array}{c}\text { Energy Savings } \\
\mathbf{( M M B t u / y r )}\end{array}$ & $\begin{array}{c}\text { 1st Year } \\
\text { Savings } \\
\mathbf{( \$ / y r )}\end{array}$ & $\begin{array}{c}\text { Installed } \\
\text { Cost } \mathbf{( \$ )}\end{array}$ & $\begin{array}{c}\text { Net Present } \\
\text { Value (\$) }\end{array}$ & \multicolumn{1}{c|}{ SIR } & $\begin{array}{c}\text { Simple } \\
\text { Payback } \\
\text { (yr) }\end{array}$ \\
\hline Envelope & 1,719 & 84,592 & 202,462 & 400,639 & 3.0 & 2.4 \\
\hline Cooling & 911 & 36,355 & 155,552 & 124,378 & 1.8 & 4.3 \\
\hline Hot Water & 429 & 12,443 & 22,397 & 98,301 & 5.4 & 1.8 \\
\hline Lighting & 7,206 & 241,539 & $1,588,073$ & 694,921 & 1.4 & 6.6 \\
\hline Total & $\mathbf{9 , 4 4 6}$ & $\mathbf{3 7 4 , 9 2 9}$ & $\mathbf{1 , 7 3 5 , 1 3 1}$ & $\mathbf{1 , 2 1 8 , 4 6 0}$ & $\mathbf{1 . 7}$ & $\mathbf{3 . 4}$ \\
\hline
\end{tabular}

In addition to this report, the Pearl Harbor energy manager will receive a complete record of the FEDS input and output files. The FEDS input files consist of the relevant building and equipment data collected and the assumptions made to perform the complex engineering analysis. The FEDS output files contain considerably more detail in support of future project development. 


\section{Emissions Reduction}

Implementing all the cost-effective building retrofits using appropriated funds will result in a $18 \%$ reduction in greenhouse gas emissions. These reductions are summarized in table ES.3 and included for each building in appendix C.

Table ES.3. Emissions Reduction from Cost-Effective Retrofits

\begin{tabular}{|l|r|}
\hline \multicolumn{1}{|c|}{ Greenhouse Gas } & \multicolumn{1}{c|}{ Reduction } \\
\hline Sulfur Oxides (lb) & 42,561 \\
\hline Nitrogen Oxides (lb) & 20,354 \\
\hline Carbon Monoxide (lb) & 35,023 \\
\hline Carbon Dioxide (tons) & 4,314 \\
\hline Particulate Matter (lb) & 843 \\
\hline Hydrocarbons (lb) & 10,088 \\
\hline
\end{tabular}

\section{Job Creation}

The jobs created from implementation of all the cost-effective retrofits using appropriated funds total 37 job-years. One job-year is equal to $\$ 92,000$ in capital spending for implementation. 


\section{Contents}

Executive Summary ............................................................................................................. iii

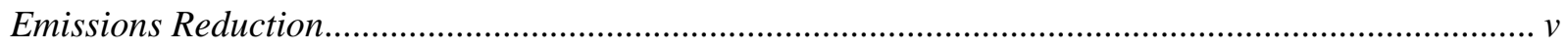

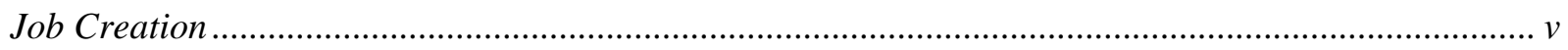

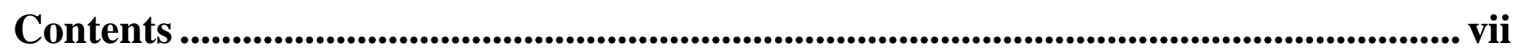

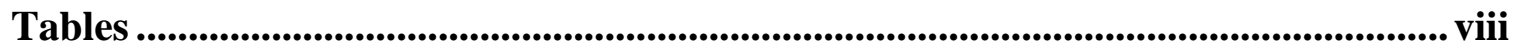

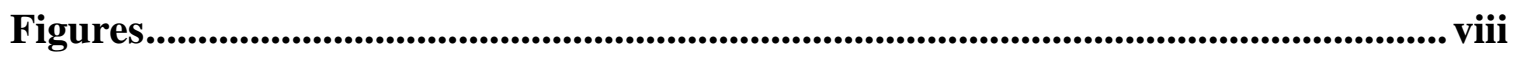

Description of ARRA program ....................................................................................................... 1

Background ...................................................................................................................................... 3

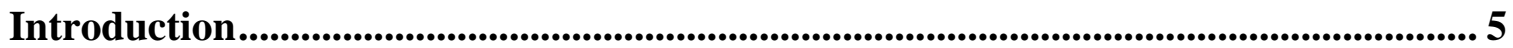

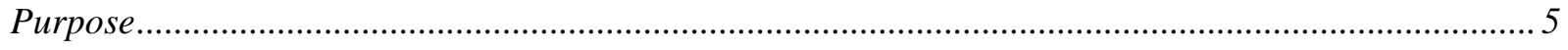

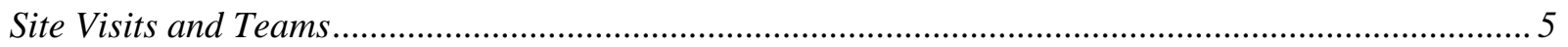

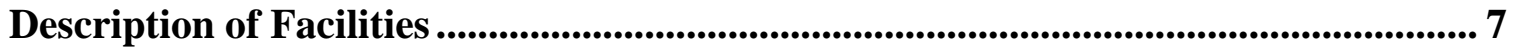

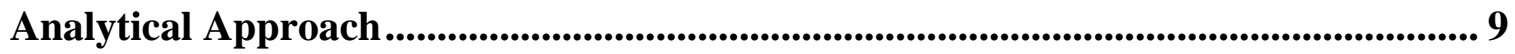

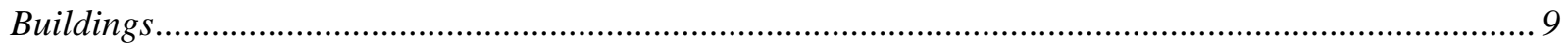

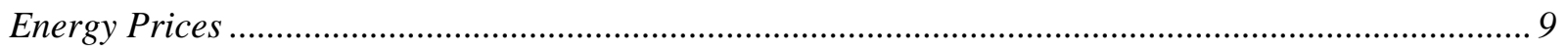

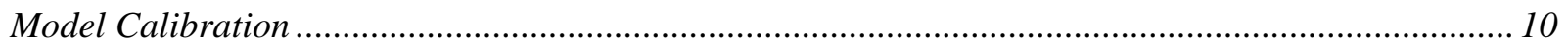

Description of Opportunities Identified .............................................................................. 11

Conversion to Water-Cooled Chillers ............................................................................... 15

Recommendations for More In-Depth Assessments .................................................. 17

Implementation Options........................................................................................ 19

Emissions Reduction........................................................................................................... 21

Contacts ............................................................................................................................................ 23

Appendix A FEDS Data Collection Form...................................................................... 27

Appendix B-1 Comprehensive List of Cost-Effective Projects Identified from the FEDS Assessment Using Appropriated Sources of Capital .................................................... 31

Appendix B-2 Comprehensive List of Cost-Effective Projects Identified from the FEDS Assessment Using Alternative Financing Sources of Capital ....................................... 39

Appendix C Energy Conservation Measures for Pearl Harbor Buildings................. 47

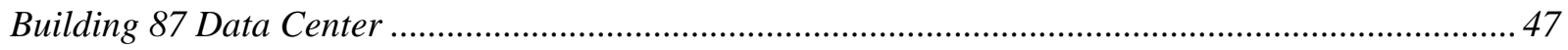

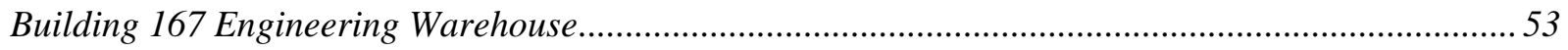

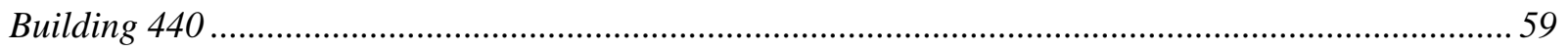

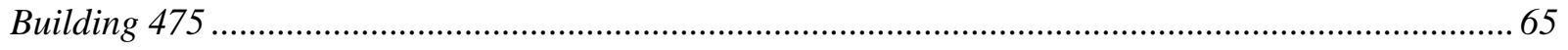

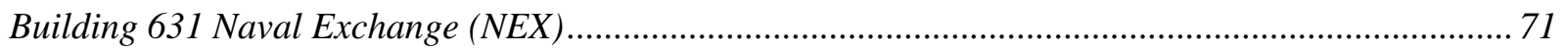

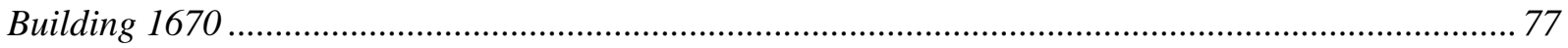

Appendix D: Conversion to Water-Cooled Chillers for Building Space Cooling ..... 85 


\section{Tables}

Table ES.1. Summary of Potential Energy and Cost Savings for Pearl Harbor Using the Appropriated Funds Source of Capital ............................................................................ iv

Table ES.2. Summary of Potential Energy and Cost Savings for Pearl Harbor Using the Alternative Financing Source of Capital.............................................................................. iv

Table ES.3. Emissions Reduction from Cost-Effective Retrofits............................................. v

Table 1. Buildings Audited ..................................................................................................... 7

Table 2. Marginal Electricity Rates for Pearl Harbor ........................................................ 10

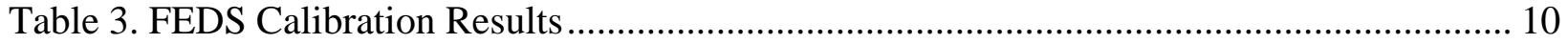

Table 4a. Summary of All Cost-Effective Projects Identified from the FEDS Assessment for

Pearl Harbor Using Appropriated Sources of Capital (by Retrofit Category and Type)...... 12

Table 4b. Summary of All Cost-Effective Projects Identified from the FEDS Assessment for

Pearl Harbor Using Alternative Financing Sources of Capital (by Retrofit Category and

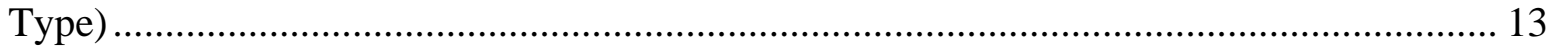

Table 5. Pearl Building 631 Existing System Performance and Electricity Cost...................... 16

Table 6. Comparison of Funding Sources............................................................................... 19

Table 7. Reduction in Greenhouse Gas Emissions .................................................................. 21

Table B-1 Comprehensive List of Cost-Effective Projects Using Appropriated Sources of Capital

Table B-2 Comprehensive List of Cost-Effective Projects Using Alternative Financing Sources

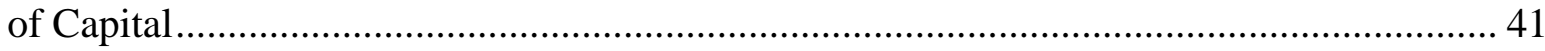

Table D1. Hickam Buildings 2130, 2131, 2133 Existing System Performance and Electricity

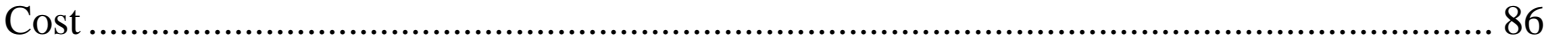

Table D2. Pearl Building 631 Existing System Performance and Electricity Cost .................... 87

Table D3. Smith Buildings 401-404, and Building 20 Existing System Performance and

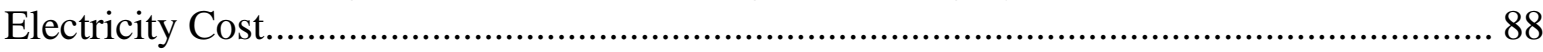

\section{Figures}

Figure 1: Military Installations on O`ahu, Hawai i .............................................................. 3

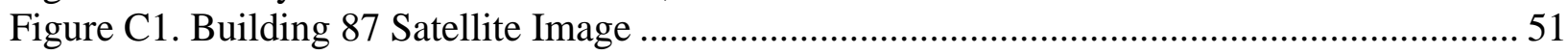

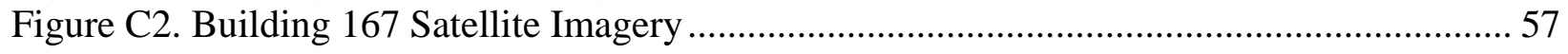

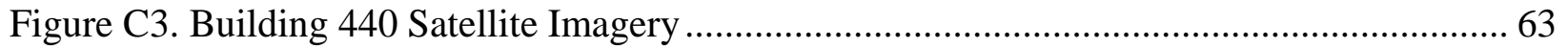

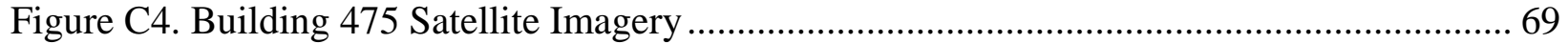

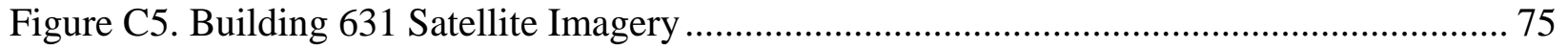

Figure C6. Miscellaneous Photos of NEX ........................................................................ 75

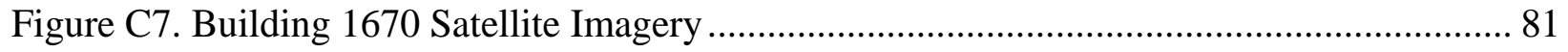




\section{Description of ARRA program}

On February 13, 2009, Congress passed the American Recovery and Reinvestment Act (ARRA) of 2009 at the urging of President Obama, who signed it into law four days later. A direct response to the economic crisis, the Recovery Act has three immediate goals:

- Create new jobs and save existing ones

- Spur economic activity and invest in long-term growth

- Foster unprecedented levels of accountability and transparency in government spending. ${ }^{1}$

The U.S. Pacific Command (USPACOM or PACOM) is facing significant energy challenges and has identified the need for a comprehensive and integrated approach to addressing these challenges. In a letter dated March 30, 2009, the PACOM Director of Resources and Assessments requested the support of the Department of Energy Federal Energy Management Program (DOE FEMP) in specific assessment, analysis, and training tasks to work toward the accomplishment of PACOM's energy security strategy. An integrated set of ARRA proposals for FEMP assistance requested national laboratory support for the execution of the identified tasks. The resulting 2009-2010 FEMP PACOM scope of work includes renewable energy and efficiency assessments, energy manager training and development, smart grid and islanding feasibility studies, alternative contracting assistance, and technology demonstrations.

In a competitive grant approach across the services and commands, the national laboratories were awarded over \$3,000,000 from DOE FEMP to support PACOM needs. The funds are dedicated to technical assistance projects aimed at bringing the most advanced energy efficiency, renewable power generation, and microgrid assessments and analyses to DOD installations in Hawai i and throughout the Pacific region.

This comprehensive building energy efficiency assessment represents a single task (Task 2.1, FEMP project 237) in the larger PACOM, ARRA-funded energy program.

\footnotetext{
${ }^{1}$ http://www.recovery.gov/
} 


\section{Background}

The United States' oldest combatant command, U.S. Pacific Command (PACOM) has been a force for peace and a committed partner in the Asia-Pacific region for more than 60 years. With an area of responsibility (AOR) that includes more than 3.4 billion people and encompasses about half the Earth's surface, the Command remains a significant stabilizing influence in the world. PACOM is supported by four component commands: U.S. Pacific Fleet, U.S. Pacific Air Forces, U.S. Army Pacific, and U.S. Marine Corps Forces, Pacific. These commands are headquartered in Hawaii and have forces stationed and deployed throughout the region.

On an average day, U.S. military forces in Hawaii require $3 \mathrm{GW}$ of electricity, representing approximately $10 \%$ of the total electricity needs of the islands. A map of military sites on Oahu is included in Figure 1 below. Facilities on other islands include: Pacific Missile Range Facility (PMRF) on Kaua i, Pohakuloa Training Area (PTA) and Kilauea Military Center (KMC) on Hawai i Island, and the Maui High Performance Computing Center (MHPCC) on Maui. In addition to most of these sites, the FEMP PACOM program tasks are performing work in Alaska, Guam, and Japan.

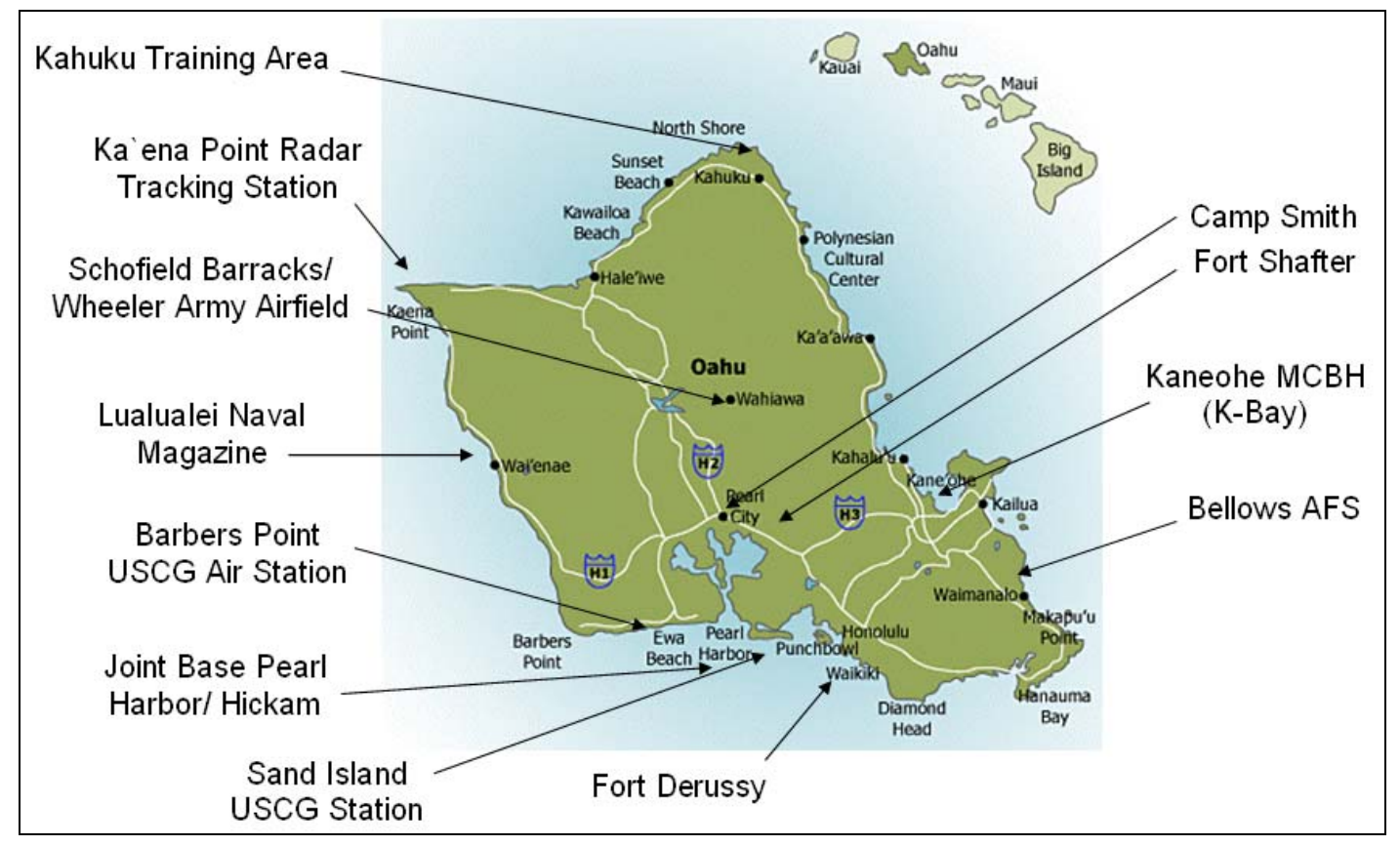

Figure 1: Military Installations on O`ahu, Hawai`i

Joint Base Pearl Harbor-Hickam (JBPHH) is in the process of combining two historic bases into a single joint installation to support both Air Force and Navy missions, along with the tenant commands, and all the service members and their families. By capitalizing on best practices of both services, they will continue to enhance the warfighting readiness, maximize delivery of installation support services throughout the joint base, and capture identified efficiencies. 


\section{Introduction}

This report contains the results of the comprehensive building energy efficiency assessment conducted at Pearl Harbor, Hawaii, by Pacific Northwest National Laboratory (PNNL). The scope of this activity was based on using the Facility Energy Decision System (FEDS) process to identify cost-effective energy- and cost-reduction projects. Six buildings were selected for detailed energy audits of sufficient scope to comply with Energy Independence and Security Act (EISA), section 432 requirements for energy and water evaluations at covered facilities. The results of the FEDS assessment will be used by the installation to develop an implementation plan for the energy conservation measures identified, and outline how Pearl Harbor will meet the goals of Executive Order 13423 by FY 2015.

\section{Purpose}

The purpose of this report is to present the findings resulting from the site visit performed January 19-29, 2010, and subsequent modeling and analysis. The objective of the site visit was to collect the necessary data to conduct building assessments using the FEDS model, resulting in a list of cost-effective, energy- and cost-reduction projects for Pearl Harbor.

\section{Site Visits and Teams}

The formal kickoff of the site assessment at Pearl Harbor was held on the morning of January 19, 2010. The PNNL team presented an overview of the FEDS assessment process, the data requirements, and schedule for the Pearl Harbor work. Participating in this meeting were:

1. Jared Strebel - Resource Efficiency/Energy Manager, NAVFAC Hawaii

2. Randy Grant - JBPHH Energy Manager

3. Jill Sims - Project Manager/Technical Lead, SENTECH Hawaii

4. Roger Dunn- Resource Efficiency Manager, JBPHH

5. Doug Dixon - PNNL

6. Daryl Brown - PNNL

7. Bill Chvála - PNNL

8. Marcus De La Rosa - PNNL 


\section{Description of Facilities}

The scope of the FEDS assessment performed at Pearl Harbor was limited to six buildings selected by Pearl Harbor personnel. Table 1 identifies the six buildings audited at Pearl Harbor and their individual and collective floor space.

\section{Table 1. Buildings Audited}

\begin{tabular}{|l|c|c|}
\hline Facility Functions & $\begin{array}{c}\text { Proxy } \\
\text { Facility } \\
\text { No. }\end{array}$ & $\begin{array}{c}\text { Building } \\
\text { Floor space } \\
\text { (sq. ft.) }\end{array}$ \\
\hline Data Center & 87 & 53,724 \\
\hline Storage and Offices & 167 & 450,000 \\
\hline Maintenance Shops and Offices & 440 & 68,232 \\
\hline Storage, Offices, and Data Center & 475 & 288,000 \\
\hline Navy Exchange & 631 & 285,515 \\
\hline Maintenance Shops and Offices & 1670 & 141,354 \\
\hline Total & & $\mathbf{1 , 2 8 6 , 8 2 5}$ \\
\hline
\end{tabular}




\section{Analytical Approach}

The general approach was to develop a FEDS model of the buildings audited at Pearl Harbor, calibrate that model to actual FY 2009 energy use with FY 2009 weather data, and then utilize the model to predict energy consumption and identify cost-effective retrofits under typical meteorological year (TMY) weather conditions.

\section{Buildings}

Six buildings were selected by Pearl Harbor personnel for the FEDS assessments. Building characteristics were developed from a combination of inferencing relationships within the FEDS model (driven by building type, size, climate, and vintage), walk-through audits of selected buildings at Pearl Harbor, and additional building data collected while visiting the Base.

\section{Energy Prices}

Hickam Air Force Base, Pearl Harbor, and Camp Smith (hereinafter, Hickam, Pearl, and Smith) are all served by Hawaiian Electric Company (HECO) under Schedule PP, Large Power Primary Voltage Service. Minor differences in the marginal electricity costs for the three organizations stem from differences in their power factors and the use of Rider M, Off-Peak and Curtailable Services, by Pearl.

The root marginal demand charge for Schedule PP is $\$ 11.85 / \mathrm{kW}$. Energy charges are billed per a declining block structure that is a function of the peak demand. This effectively results in an additional $\$ 2.78 / \mathrm{kW}$ demand charge because an increase in demand shifts more energy into higher-priced blocks. The first $200 \mathrm{kWh} / \mathrm{kW}$ are billed at $\$ 0.121534 / \mathrm{kWh}$, and the second 200 $\mathrm{kWh} / \mathrm{kW}$ are billed at $\$ 0.113702 / \mathrm{kWh}$. All $\mathrm{kWh}$ in excess of $400 \mathrm{kWh} / \mathrm{kW}$ are billed at $\$ 0.110668 / \mathrm{kWh}$. The demand profiles at Hickam, Pearl, and Smith all result in the marginal $\mathrm{kWh}$ being billed at the rate for the third block.

Several adjustments are applied that affect the marginal electricity cost. The total bill is decreased by $0.1 \%$ for each $1 \%$ that power factors are above $85 \%$ (and vice-versa if the power factor is below 85\%). "Interim" increases in the rates established in 2007 and 2009 add 2.82\% to the total bill. Finally, the combination of public benefit funds, energy cost, and integrated resource planning surcharges add a little more than $\$ 0.03$ to the cost of each $\mathrm{kWh}$.

The billing demand for each month is the higher of the actual peak demand for that month or the average of peak demand for that month and the peak demand for the previous 11 months. This structure cannot be directly modeled in FEDS, but was found to be equivalent to a $92 \%$ annual demand ratchet, which can be modeled in FEDS.

Pearl utilizes Rider $\mathrm{M}$ to reduce its demand charge by agreeing to reduce its load from 5-9 PM, Monday through Friday. This rider reduces its billing demand by $75 \%$ of the difference between its overall peak demand and its peak demand during the 5-9 PM period. For Pearl, the Rider M billing demand averaged $96 \%$ of its actual peak demand during 2009. This is equivalent to using the actual peak demand as the billing demand and reducing the demand charge by $4 \%$, which was the modeling approach used for FEDS. 
The resulting marginal electricity costs are summarized in Table 2.

Table 2. Marginal Electricity Rates for Pearl Harbor

\begin{tabular}{|l|c|}
\hline Rate Component & Pearl \\
\hline Demand Charge, \$/kW & 14.24 \\
\hline Energy Charge, \$/kWh & 0.1426 \\
\hline Effective Demand Ratchet, \% & N/A \\
\hline
\end{tabular}

\section{Model Calibration}

Building energy use was simulated with FEDS to predict the total site energy consumption for FY 2009 using FY 2009 weather data. Uncertain elements of the modeling assumptions were adjusted until the model's energy consumption prediction matched "reasonably well" with actual energy consumption for FY 2009. Specific model calibration results are shown in Table 3. ${ }^{2}$

Table 3. FEDS Calibration Results

\begin{tabular}{|l|l|c|}
\hline Building Number & Fuel Type & $\begin{array}{c}\text { Error } \\
\text { (\%) }\end{array}$ \\
\hline 87 & Electricity & 0.3 \\
\hline 167 & Electricity & 0.5 \\
\hline 440 & Electricity & 0.0 \\
\hline 475 & Electricity & 0.8 \\
\hline 631 & Electricity & 2.2 \\
\hline 1670 & Electricity & -1.0 \\
\hline
\end{tabular}

\footnotetext{
${ }^{2}$ For example, an error of $+0.5 \%$ means that the model predicts energy consumption $0.5 \%$ higher than reported consumption.
} 


\section{Description of Opportunities Identified}

The number of conceivable energy conservation measures, fuel-switching opportunities, and renewable-energy projects at federal sites is very large. The FEDS model is used to costeffectively identify energy saving opportunities. FEDS is a software tool that provides a comprehensive method to quickly and objectively identify energy improvements that offer maximum life-cycle cost savings. FEDS determines the optimum set of cost-effective retrofits from a current database of hundreds of proven technologies. These include retrofits for heating, cooling, lighting, motors, building envelope, and hot water systems. Interactive effects are also evaluated as part of the optimization process so that energy savings are not double counted or undercounted. The results are based on life-cycle cost economics consistent with 10 CFR 436.

FEDS identifies the package of retrofits that individually and collectively minimize the life-cycle cost of building energy services, resulting in projects where the net present value (NPV) of the investment is greater than or equal to zero and the savings-to-investment ratio (SIR) is greater than or equal to one. Results are developed for government (appropriated) and alternative (e.g., ESPC and Utility Energy Service Contracting [UESC]) financing assumptions.

In general, the discount rate is higher and the economic evaluation life is shorter for alternative financing compared to government financing. The economic life for the latter is set at 25 years with the discount rate adjusted each year in response to market conditions. The currently prescribed government discount rate is 3.0\% in real terms, i.e., in excess of general inflation. Alternative financing assumptions are not prescribed, but set by negotiation between the ESCO and the federal organization. An economic evaluation life of 10 years and a real discount rate of $10 \%$ are used to represent alternative financing conditions in this assessment, based on a collection of prior site experiences in the Army.

Table 4a summarizes the FEDS results by retrofit category (e.g., cooling) and type (e.g., chillers) using appropriated funding as the source of capital for the projects. Table $4 \mathrm{~b}$ summarizes the FEDS results by retrofit category using alternative financing as the source of capital for the projects. The complete list of cost-effective energy- and cost-reduction projects resulting from the FEDS modeling and analysis are presented Appendices B-1 (appropriated funds) and B-2 (alternative financing). ${ }^{3}$

\footnotetext{
${ }^{3}$ It should be noted that in addition to this report, the Pearl Harbor energy manager will also receive a CD-ROM, which includes all the FEDS input data and output project files. The input data files reflect information collected during the site visits and additional assumptions required to perform the FEDS modeling and assessment. The output project files contain significantly more detailed information to support the list of cost-effective energy projects identified in Appendices B-1 and B-2.
} 
Table 4a. Summary of All Cost-Effective Projects Identified from the FEDS Assessment for Pearl Harbor Using Appropriated Sources of Capital (by Retrofit Category and Type)

\begin{tabular}{|c|c|c|c|c|c|c|c|}
\hline $\begin{array}{l}\text { Retrofit } \\
\text { Category }\end{array}$ & Retrofit Type & $\begin{array}{c}\text { Energy } \\
\text { Savings } \\
\text { (MMBtu/yr) }\end{array}$ & $\begin{array}{c}\text { 1st Year } \\
\text { Savings } \\
\text { (\$/yr) }\end{array}$ & $\begin{array}{l}\text { Installed } \\
\text { Cost (\$) }\end{array}$ & $\begin{array}{c}\text { Net } \\
\text { Present } \\
\text { Value (\$) }\end{array}$ & SIR & $\begin{array}{c}\text { Simple } \\
\text { Payback } \\
\text { (yr) }\end{array}$ \\
\hline \multirow[t]{2}{*}{ Envelope } & $\begin{array}{l}\text { Roof/Attic } \\
\text { Insulation }\end{array}$ & 2,158 & 76,742 & 413,561 & 894,072 & 3.2 & 5.4 \\
\hline & Subtotal & 2,158 & 76,742 & 413,561 & 894,072 & 3.2 & 5.4 \\
\hline \multirow[t]{2}{*}{ Cooling } & $\begin{array}{l}\text { Water-Cooled } \\
\text { Chillers } \\
\end{array}$ & 3,893 & 197,942 & $1,254,765$ & $1,023,281$ & 1.8 & 6.3 \\
\hline & Subtotal & 3,893 & 197,942 & $1,254,765$ & $1,023,281$ & 1.8 & 6.3 \\
\hline \multirow[t]{3}{*}{ Hot Water } & $\begin{array}{l}\text { Heat Pump Water } \\
\text { Heaters }\end{array}$ & 416 & 20,020 & 24,921 & 74,494 & 4.0 & 1.2 \\
\hline & $\begin{array}{l}\text { Tank and Pipe } \\
\text { Insulation }\end{array}$ & 31 & 1,531 & 1,875 & 7,060 & 4.8 & 1.2 \\
\hline & Subtotal & 447 & 21,551 & 26,796 & 81,554 & 4.0 & 1.2 \\
\hline \multirow[t]{5}{*}{ Lights } & $\begin{array}{l}\text { Compact } \\
\text { Fluorescents (CFLs) }\end{array}$ & 182 & 12,285 & 1,448 & 205,235 & 143 & 0.1 \\
\hline & $\begin{array}{l}\text { Electroluminescent } \\
\text { Exit Signs }\end{array}$ & 14 & 2,977 & 17,352 & 34,006 & 3.0 & 5.8 \\
\hline & $\begin{array}{l}\text { T-8s, other } \\
\text { Fluorescents }\end{array}$ & 6,917 & 346,827 & $1,660,551$ & $4,139,621$ & 3.5 & 4.8 \\
\hline & $\begin{array}{l}\text { High Pressure } \\
\text { Sodium Lamps }\end{array}$ & 93 & 5,086 & 49,901 & 34,858 & 1.7 & 9.8 \\
\hline & Subtotal & 7,206 & 367,175 & $1,729,252$ & $4,413,720$ & 3.6 & 4.7 \\
\hline \multicolumn{2}{|l|}{ Total } & 13,704 & 663,410 & $3,424,374$ & $6,412,627$ & 2.9 & 5.2 \\
\hline
\end{tabular}

From Table 4a, the total cost-effective energy savings is estimated at 13,704 MMBtu/year representing $\$ 663,410 /$ year savings with an overall savings to investment ratio (SIR) of 2.9.

The greatest energy saving potential was found in lighting measures (7,206 MMBtu/year), followed by cooling (3,893 MMBtu/year). The largest estimated dollar savings was also found in lighting (\$367,175/year), again followed by cooling (\$197,942/year). Hot water measures (4.0) followed by lighting (3.6) showed the greatest SIR. 
Table 4b. Summary of All Cost-Effective Projects Identified from the FEDS Assessment for Pearl Harbor Using Alternative Financing Sources of Capital (by Retrofit Category and Type)

\begin{tabular}{|c|c|c|c|c|c|c|c|}
\hline $\begin{array}{c}\text { Retrofit } \\
\text { Category }\end{array}$ & Retrofit Type & $\begin{array}{c}\text { Energy } \\
\text { Savings } \\
\text { (MMBtu/yr) }\end{array}$ & $\begin{array}{l}\text { 1st Year } \\
\text { Savings } \\
(\$ / y r) \\
\end{array}$ & $\begin{array}{l}\text { Installed } \\
\text { Cost (\$) }\end{array}$ & $\begin{array}{c}\text { Net Present } \\
\text { Value (\$) }\end{array}$ & SIR & $\begin{array}{c}\text { Simple } \\
\text { Payback } \\
\text { (yr) }\end{array}$ \\
\hline \multirow{2}{*}{ Envelope } & Roof/Attic Insulation & 1,719 & 84,592 & 202,462 & 400,639 & 3.0 & 2.4 \\
\hline & Subtotal & 1,719 & 84,592 & 202,462 & 400,639 & 3.0 & 2.4 \\
\hline \multirow[t]{3}{*}{ Cooling } & Packaged A/C Units & 32 & 6,132 & 35,326 & 2,352 & 1.1 & 5.7 \\
\hline & $\begin{array}{l}\text { Water-Cooled } \\
\text { Chillers }\end{array}$ & 879 & 30,223 & 120,226 & 122,026 & 2.0 & 4.0 \\
\hline & Subtotal & 911 & 36,355 & 155,552 & 124,378 & 1.8 & 4.3 \\
\hline \multirow[t]{3}{*}{ Hot Water } & $\begin{array}{l}\text { Heat Pump Water } \\
\text { Heaters }\end{array}$ & 402 & 11,548 & 21,454 & 91,264 & 5.3 & 1.9 \\
\hline & $\begin{array}{l}\text { Tank and Pipe } \\
\text { Insulation }\end{array}$ & 27 & 895 & 943 & 7,037 & 8.5 & 1.1 \\
\hline & Subtotal & 429 & 12,443 & 22,397 & 98,301 & 5.4 & 1.8 \\
\hline \multirow[t]{5}{*}{ Lights } & $\begin{array}{l}\text { Compact } \\
\text { Fluorescents (CFLs) }\end{array}$ & 451 & 16,240 & 4,485 & 173,664 & 39.7 & 0.3 \\
\hline & $\begin{array}{l}\text { Electroluminescent } \\
\text { Exit Signs }\end{array}$ & 13 & 2,549 & 14,667 & 846 & 1.1 & 5.8 \\
\hline & $\begin{array}{l}\text { T-8s, other } \\
\text { Fluorescents }\end{array}$ & 6,721 & 221,981 & $1,563,792$ & 519,556 & 1.3 & 7.0 \\
\hline & $\begin{array}{l}\text { High Pressure } \\
\text { Sodium Lamps }\end{array}$ & 21 & 769 & 5,129 & 855 & 1.2 & 6.7 \\
\hline & Subtotal & 7,206 & 241,539 & $1,588,073$ & 694,921 & 1.4 & 6.6 \\
\hline \multicolumn{2}{|l|}{ Total } & 9,446 & 374,929 & $1,735,131$ & $1,218,460$ & 1.7 & 3.4 \\
\hline
\end{tabular}

From Table 4b, the total cost-effective energy savings is estimated at 9,446 MMBtu/year representing $\$ 374,929 /$ year savings with an overall savings to investment ratio (SIR) of 1.7.

The greatest energy saving potential was found in lighting measures (7,206 MMBtu/year), followed by envelope measures - insulation (1,719 MMBtu/year). The largest estimated dollar savings was also found in lighting ( $\$ 241,539 /$ year), again followed by envelope measures (\$84,592/year). Hot water (5.4) followed by envelope measures (3.0) showed the greatest SIR.

As would be expected, the total number of cost-effective retrofits is fewer (and installed cost/ capital investment is less) under alternative financing sources of capital, and thus, the energy and dollar savings are likewise less. The total number of cost-effective retrofits using appropriated sources of capital is 72 and the total number of cost-effective retrofits using alternative financing sources of capital is 38. Using appropriated funding will save 4,258 MMBtu/year and $\$ 288,481$ year more than alternative financing. Utilizing alternative financing reduces the simple payback from 5.2 to 3.4 years because many projects with longer paybacks are eliminated under the alternative financing scenario. 
The complete list of cost-effective energy- and cost-reduction projects is given Appendix B-1 for appropriated funding and in Appendix B-2 for alternative financing. ${ }^{4}$

\footnotetext{
${ }^{4}$ The Pearl Harbor energy manager will also receive a CD, which includes all the FEDS input data and output project files. The input data files reflect information collected during the site visits and additional assumptions required to perform the FEDS modeling and assessment.
} 


\section{Conversion to Water-Cooled Chillers}

Water-cooled condensing of cooling equipment refrigerant results in a significant improvement in efficiency compared to air-cooled condensing chillers. This advantage stems from two factors. Condenser water from an evaporative cooling tower is generally cooler than ambient air (except when the relative humidity is very high), and water is a more effective heat transfer fluid than air. The two factors work together to lower the refrigerant condensing temperature, which improves both theoretical and actual refrigeration cycle efficiency. Combining cooling loads met by multiple smaller cooling units into fewer central units allows additional efficiency gains by using centrifugal compressors, a more efficient technology than alternative compressor types commonly used in smaller cooling equipment. These advantages do come at a price, however. Condensing refrigerant with water requires additional costs associated with a cooling tower, condenser water pumps and piping, and a shell to enclose the water as it passes by the condenser tubing. The condenser pump also represents an additional power consuming device that an aircooled unit does not have. Finally, the distribution of centrally chilled water incurs pumping and piping costs and pumping energy not required by distributed direct expansion coolers (e.g., window air conditioner [AC] and packaged rooftop AC).

For the reasons noted above, water-cooled chillers offer significant performance advantages over air-cooled equipment that must be weighed against their additional capital costs. During the last few decades, space cooling has become much more common in Hawaiian military facilities because internal heating loads (e.g., personal computers and other office equipment) have increased, building designs have become less suitable for natural ventilation, and occupants expect a more comfortable working environment. The FEDS model generated retrofit recommendations replacing air-cooled chillers with water-cooled chillers at the building level. The following paragraphs discuss the impact of combining these energy conservation measures (ECMs) into a centralized chilled-water plant. More details of the assessment of water-cooled chillers at Hickam AFB, Pearl Harbor, and Camp Smith are provided in Appendix D.

Building 631, the Navy Exchange (NEX) and Commissary, is currently served by a collection of packaged rooftop direct expansion (DX) AC units. The proposed retrofit would replace the existing DX units with a new chilled water coil (in the existing air-handler units [AHU]), two water-cooled chillers, a cooling tower, condenser water pumps and piping, and chilled water pumps and piping. The new chiller plant was assumed to be sited on the ground on the southeast side of the building, next to the Commissary.

The peak and annual building cooling loads were estimated with the FEDS model, and the performance of the existing packaged DX units was estimated from the vintage of the existing equipment. From this information, the annual kWh and peak kW electrical loads were calculated and then combined with Pearl Harbor's electricity rates to calculate the current annual electricity costs. The existing system performance and electricity cost figures are presented in Table 5. 
Table 5. Pearl Building 631 Existing System Performance and Electricity Cost

\begin{tabular}{|l|c|c|c|c|c|c|c|}
\hline \multicolumn{1}{|c|}{ Building } & $\begin{array}{c}\text { Peak } \\
\text { Load, } \\
\text { Tons }\end{array}$ & $\begin{array}{c}\text { Annual } \\
\text { Load, } \\
\text { Ton- } \\
\text { hours }\end{array}$ & $\begin{array}{c}\text { Annual } \\
\text { Capacity } \\
\text { Factor }\end{array}$ & $\begin{array}{c}\text { Existing } \\
\text { Air } \\
\text { Cooled } \\
\text { kW/ton }\end{array}$ & $\begin{array}{c}\text { Existing } \\
\text { Annual } \\
\text { Electricity } \\
\text { kWh }\end{array}$ & $\begin{array}{c}\text { Existing } \\
\text { Peak } \\
\text { Electricity } \\
\text { kW }\end{array}$ & $\begin{array}{c}\text { Existing } \\
\text { Annual } \\
\text { Electricity } \\
\text { Cost }\end{array}$ \\
\hline $\begin{array}{l}\text { Navy } \\
\text { Exchange } \\
\text { (NEX) }\end{array}$ & 275.1 & 918,580 & 0.38 & 1.2859 & $1,181,180$ & 354 & \\
\hline $\begin{array}{l}\text { NEX Food } \\
\text { Court }\end{array}$ & 125.0 & 342,737 & 0.31 & 1.2859 & 440,717 & 161 & \\
\hline Commissary & 194.4 & 716,633 & 0.42 & 1.2859 & 921,501 & 250 & \\
\hline Totals & 594.5 & $1,977,950$ & 0.38 & 1.2859 & $2,543,446$ & 764 & $\$ 493,300$ \\
\hline
\end{tabular}

In this size range, the water-cooled chillers were assumed to use a centrifugal compressor rated at $0.51 \mathrm{~kW} / \mathrm{ton}$. In addition, the chilled water pumps, condenser water pumps, and cooling tower fan would be expected to consume $0.18 \mathrm{~kW} /$ ton, for a total cooling plant performance of 0.69 $\mathrm{kW} / \mathrm{ton}$. The annual electricity bill for the water-cooled system was calculated to be $\$ 264,700$ based on these assumptions, resulting in an annual savings of $\$ 228,600$ and a peak electric load reduction of $354 \mathrm{~kW}$.

A new 600-ton water-cooled chiller plant (chillers, cooling tower, pumps, plant piping, electrical, controls, and structure) was estimated to cost $\$ 656,000$. Chilled water piping running to and from the ground to every rooftop air-handling unit was estimated to cost $\$ 225,000$. The cost of the new chilled water coils was estimated to be $\$ 180,000$. These figures include all direct construction costs, but do not include any allowance for design or SIOH costs. Based on the direct cost, the payback period is 4 years. With an additional $16 \%$ for design and SIOH, the payback period rises to 4.5 years. 


\section{Recommendations for More In-Depth Assessments}

The FEDS model can provide an unbiased assessment of literally hundreds of energy conservation projects; unfortunately, it is not all-inclusive. While the scope of this project is limited to energy-saving projects included in the FEDS model, the energy-saving opportunities identified below were recognized during the site visit and may be worth additional consideration by the site energy staff. It is recommended that the site pursue additional assessments of these potential projects.

Cool Roofs. FEDS does not evaluate the potential savings for cool roof projects.

Building Controls. Recommendations for building controls cannot be easily inferred by the FEDS model engine. A detailed building assessment focused on all heating, ventilation, and air conditioning (HVAC) equipment is required to develop project proposals.

Programmable Thermostats. The FEDS model does not consider programmable thermostats in the energy analysis. Programmable thermostats are considered a conservation measure rather than an equipment replacement or building improvement. Programmable thermostats could be a useful conservation measure in smaller commercial buildings or any building that is unoccupied during part of the day. 


\section{Implementation Options}

Pearl Harbor has a number of options for implementing the ECMs identified in this assessment. As shown in Table 6, implementing the building level ECMs using appropriated funds would require an investment of about \$3.4M and save 13,704 MMBtu/year or \$663,410/year with an overall savings to investment ratio (SIR) of 2.9. Implementing the ECMs with alternative financing (ESPC or UESC) would save 9,446 MMBtu/year or \$374,929/year with an overall savings to investment ratio (SIR) of 1.7 and an investment cost of $\$ 1.7 \mathrm{M}$. However, the investment cost under alternative financing does not include the financing charges over the life of the project.

The recommended option for implementing the building level ECMs would be to pursue appropriated funds, either through the ECIP program or sustainment, renovation, and modernization (SRM) at the base level. This would result in the greatest energy and cost savings to the Navy (see Table 6). The ECIP program within the Navy/Marines may not be an option for these building energy efficiency ECMs, because the focus of the current program is on renewable energy projects. If appropriated funds are not available, then alternative financing would provide the means to get most of the projects implemented without requiring a high up front investment from the Navy.

Table 6. Comparison of Funding Sources

\begin{tabular}{|l|c|c|c|c|c|c|}
\hline \multicolumn{1}{|c|}{ Funding Source } & $\begin{array}{c}\text { Energy } \\
\text { Savings } \\
\mathbf{M M B t u / y r )}\end{array}$ & $\begin{array}{c}\text { 1st Year } \\
\text { Savings } \\
\mathbf{( \$ / y r )}\end{array}$ & $\begin{array}{c}\text { Installed } \\
\text { Cost (\$) }\end{array}$ & $\begin{array}{c}\text { Estimated } \\
\text { Financing } \\
\text { Costs (\$) }\end{array}$ & $\begin{array}{c}\text { Total Cost } \\
\mathbf{( \$ )}\end{array}$ & SIR \\
\hline Appropriated funding & 13,704 & 663,410 & $3,424,374$ & 0 & $3,424,374$ & 2.9 \\
\hline Alternative financing & 9,446 & 374,929 & $1,735,131$ & $1,248,313$ & $2,983,444$ & 1.7 \\
\hline
\end{tabular}

Public Benefit funds may be available for some of these ECMs through Hawaii Energy. Hawaii Energy operates the new and expanded Hawaii Energy Efficiency Programs under contract to the Hawaii Public Utilities Commission (HPUC) and paid for by electric utility ratepayer fees.

\footnotetext{
${ }^{5}$ Assumes alternative financing at an annual interest rate of 6\% for 20 years.
} 


\section{Emissions Reduction}

Implementing all the cost-effective building retrofits using appropriated funds will result in a $18 \%$ reduction in greenhouse gas emissions. These reductions are summarized in table 7 and included for each building in appendix $\mathrm{C}$.

Table 7. Reduction in Greenhouse Gas Emissions

\begin{tabular}{|c|c|c|c|c|c|c|c|}
\hline Greenhouse Gas & $\begin{array}{c}\text { Building } \\
167 \\
\end{array}$ & $\begin{array}{c}\text { Building } \\
475\end{array}$ & $\begin{array}{c}\text { Building } \\
631 \\
\end{array}$ & $\begin{array}{c}\text { Building } \\
1670 \\
\end{array}$ & $\begin{array}{c}\text { Building } \\
87 \\
\end{array}$ & $\begin{array}{c}\text { Building } \\
440\end{array}$ & Totals \\
\hline \multicolumn{8}{|l|}{ Sulfur Oxides (lb) } \\
\hline existing & 48,430 & 54,380 & 52,842 & 17,429 & 49,228 & 11,276 & 233,585 \\
\hline post-retrofit & 43,439 & 44,784 & 38,915 & 14,164 & 41,169 & 8,553 & 191,024 \\
\hline difference & $(4,991)$ & $(9,596)$ & $(13,927)$ & $(3,265)$ & $(8,059)$ & $(2,723)$ & $(42,561)$ \\
\hline$\%$ change & 10.31 & 17.65 & 26.36 & 18.73 & 16.37 & 24.15 & 18.22 \\
\hline \multicolumn{8}{|l|}{ Nitrogen Oxides (lb) } \\
\hline existing & 23,142 & 25,986 & 25,268 & 8,328 & 23,524 & 5,388 & 111,636 \\
\hline post-retrofit & 20,758 & 21,400 & 18,596 & 6,768 & 19,673 & 4,087 & 91,282 \\
\hline difference & $(2,384)$ & $(4,586)$ & $(6,672)$ & $(1,560)$ & $(3,851)$ & $(1,301)$ & $(20,354)$ \\
\hline$\%$ change & 10.30 & 17.65 & 26.40 & 18.73 & 16.37 & 24.15 & 18.23 \\
\hline \multicolumn{8}{|l|}{ Carbon Monoxide (lb) } \\
\hline existing & 39,805 & 44,696 & 43,473 & 14,325 & 40,461 & 9,268 & 192,028 \\
\hline post-retrofit & 35,703 & 36,808 & 31,985 & 11,642 & 33,837 & 7,030 & 157,005 \\
\hline difference & $(4,102)$ & $(7,888)$ & $(11,488)$ & $(2,683)$ & $(6,624)$ & $(2,238)$ & $(35,023)$ \\
\hline$\%$ change & 10.31 & 17.65 & 26.43 & 18.73 & 16.37 & 24.15 & 18.24 \\
\hline \multicolumn{8}{|l|}{ Carbon Dioxide (tons) } \\
\hline existing & 4,902 & 5,505 & 5,353 & 1,764 & 4,983 & 1,141 & 23,648 \\
\hline post-retrofit & 4,396 & 4,533 & 3,938 & 1,434 & 4,167 & 866 & 19,334 \\
\hline difference & (506) & $(972)$ & $(1,415)$ & (330) & $(816)$ & $(275)$ & $(4,314)$ \\
\hline$\%$ change & 10.32 & 17.66 & 26.43 & 18.71 & 16.38 & 24.10 & 18.24 \\
\hline \multicolumn{8}{|l|}{ Particulate Matter (lb) } \\
\hline existing & 958 & 1,076 & 1,046 & 344 & 974 & 223 & 4,621 \\
\hline post-retrofit & 859 & 886 & 769 & 281 & 814 & 169 & 3,778 \\
\hline difference & (99) & $(190)$ & $(277)$ & (63) & $(160)$ & (54) & (843) \\
\hline$\%$ change & 10.33 & 17.66 & 26.48 & 18.31 & 16.43 & 24.22 & 18.24 \\
\hline \multicolumn{8}{|l|}{ Hydrocarbons (lb) } \\
\hline existing & 16,475 & 18,499 & 4,409 & 5,929 & 16,746 & 3,836 & 65,894 \\
\hline post-retrofit & 14,776 & 15,234 & 4,065 & 4,818 & 14,004 & 2,909 & 55,806 \\
\hline difference & $(1,699)$ & $(3,265)$ & (344) & $(1,111)$ & $(2,742)$ & $(927)$ & $(10,088)$ \\
\hline$\%$ change & 10.31 & 17.65 & 7.80 & 18.74 & 16.37 & 24.17 & 15.31 \\
\hline
\end{tabular}




\section{Contacts}

Contact information for assessment team members and site team from PNNL are:

Doug Dixon

Pacific Northwest National Laboratory

902 Battelle Boulevard, MSIN K6-10

Richland, WA 99352

Phone: (509) 372-4253

Email: doug.dixon@pnl.gov

William D. Chvala, Jr.

Pacific Northwest National Laboratory

902 Battelle Boulevard, MSIN K5-08

Richland, WA 99352

Phone: (509) 372-4558

Email: william.chvala@pnl.gov

Daryl Brown

Pacific Northwest National Laboratory

902 Battelle Boulevard, MSIN K6-10

Richland, WA 99352

Phone: (509) 372-4366

Email: daryl.brown@pnl.gov

Marcus De La Rosa

Pacific Northwest National Laboratory

902 Battelle Boulevard, MSIN K5-16

Richland, WA 99352

Phone: (509) 375-2941

Email: marcus.delarosa@pnl.gov 


\section{Appendix A}

\section{FEDS Data Collection Form}




\section{Appendix A \\ FEDS Data Collection Form}

The following form is used to collect FEDS input data during building audits. Note that not all data types indicated on this form are applicable to all buildings. Nor is all the information indicated on this form always available. Where necessary, the FEDS model infers the values for missing data based on other known building characteristics.

FEDS Building Information for

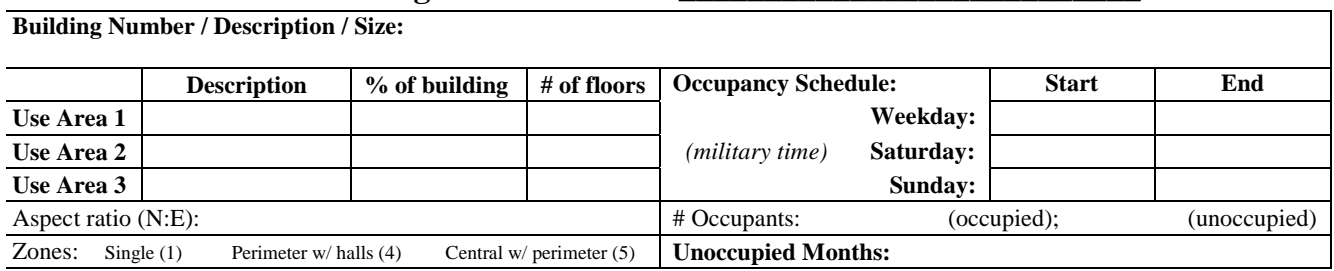

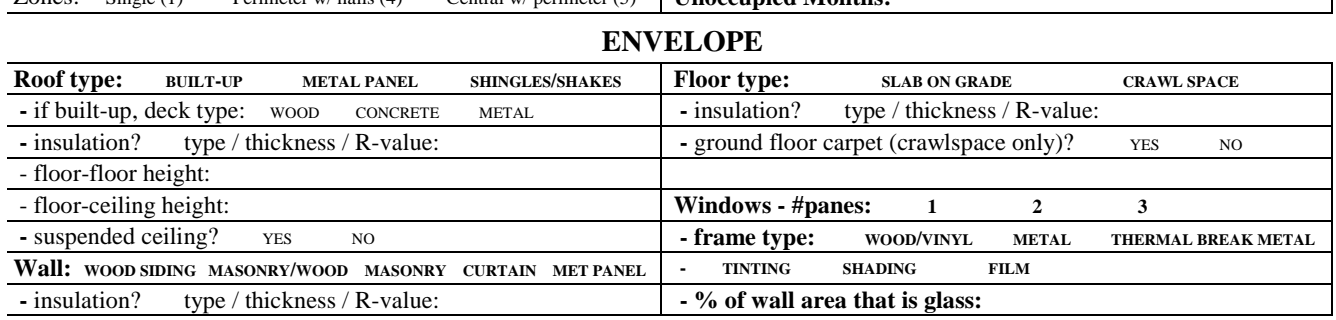

- insulation? type / thickness / R-value:

LIGHTING

\begin{tabular}{|c|c|c|c|c|c|}
\hline $\begin{array}{c}\text { Technology } \\
\text { Type }\end{array}$ & $\begin{array}{l}\text { Fixture Description (size, \#lamps, wattage, } \\
\text { reflectors, ballasts, application, etc.)* }\end{array}$ & $\begin{array}{c}\text { Use Area or \% of } \\
\text { building served }\end{array}$ & $\begin{array}{c}\begin{array}{c}\text { Fixture density } \\
\text { or count }\end{array} \\
\end{array}$ & $\begin{array}{c}\text { Mounting } \\
\text { Method }\end{array}$ & Utilization \\
\hline \multicolumn{6}{|l|}{ Exit Signs } \\
\hline & & & & & \\
\hline & & & & & \\
\hline & & & & & \\
\hline & & & & & \\
\hline & & & & & \\
\hline & & & & & \\
\hline & & Exterior & & -- & \\
\hline & & Exterior & & -- & \\
\hline & & Exterior & & -- & \\
\hline
\end{tabular}

LPS = low pressure sodium EX = exit sign $\quad$ *2-tube T12=2T12; 4-tube T12=4T12; 2-tube T8=2T8; 2-tube T5=2T5; 4-tube Biax=4BIAX

SERVICE HOT WATER

\begin{tabular}{l|l|l|l|}
\hline $\begin{array}{l}\text { Portion of building set served (whole buildings) } \\
\text { (sq. ft, \%, \# of buildings, or USE AREA) }\end{array}$ & \multicolumn{1}{|c|}{ System 1: } & System 2: & System 3: \\
\hline Fuel type & & & \\
\hline System type & DISTRIBUTED LOOP & DISTRIBUTED LOOP & DISTRIBUTED \\
\hline Equipment vintage & & & LOOP \\
\hline Tank capacity (gallons, \#tanks) & & & \\
\hline Heating capacity (loop only) & & & \\
\hline Thermostat set point, ${ }^{\mathrm{F}}$ & & & \\
\hline Tank insulation - thickness/R-value & & & \\
\hline Efficiency & & & \\
\hline Loop length (perimeter or stacked service) & & & \\
\hline \#Faucets / aerators installed (\%) & & & \\
\hline \#Showers / low-flow showerheads installed (\%) & & & \\
\hline $\begin{array}{l}\text { Note presence of: bottom boards, near tank pipe } \\
\text { insul., tank wrap, heat traps, electronic pilots }\end{array}$ & & & \\
\hline
\end{tabular}

Auditor:

Date:

Sheet of 
HVAC

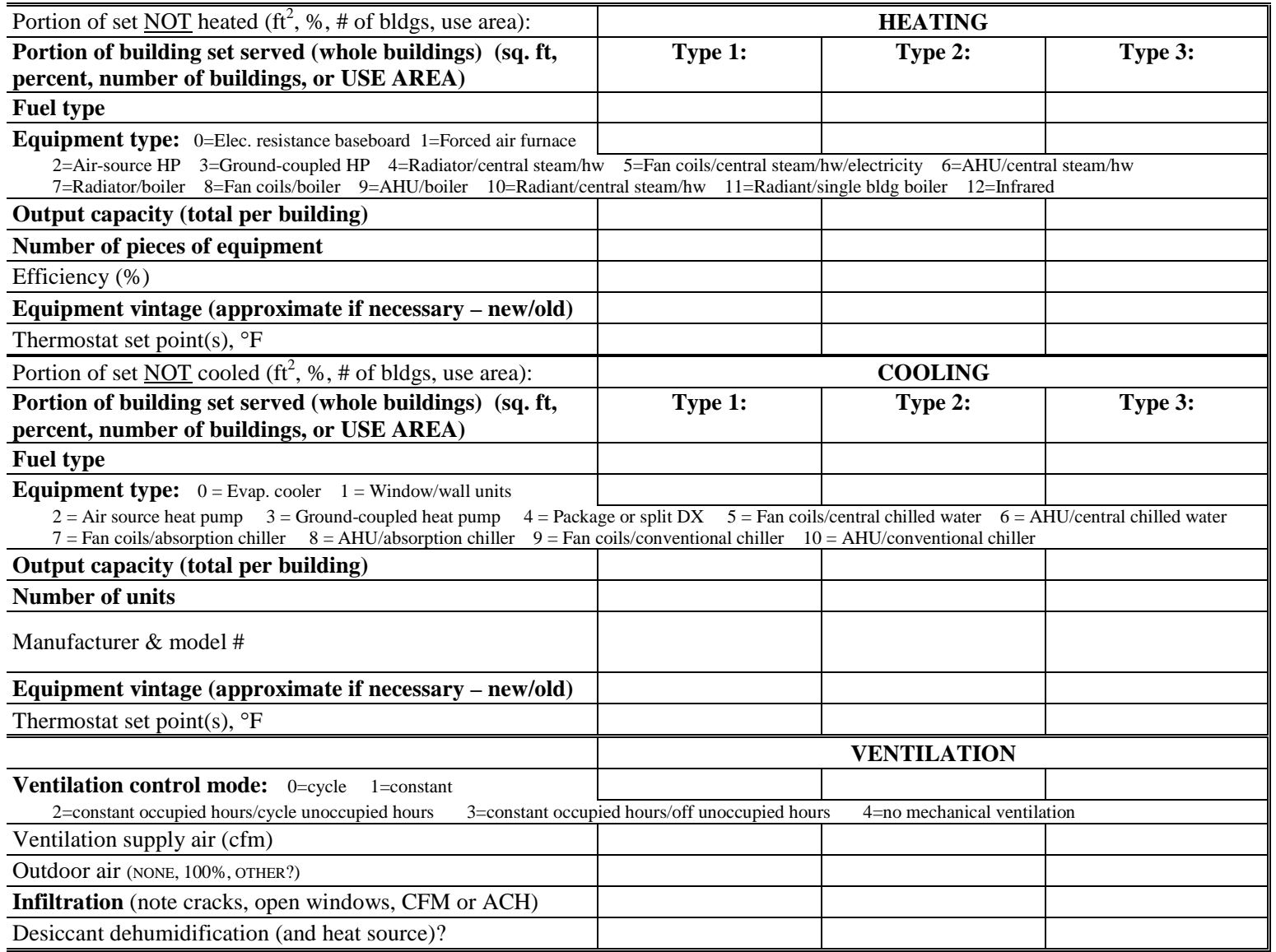

MISC. EQUIPMENT

Refrigeration, food prep, or other - note if irregular. Atypical equipment: description including type, fuel, capacity, utilization.

\begin{tabular}{|c|c|c|c|c|}
\hline \multicolumn{5}{|c|}{ MOTORS } \\
\hline & Type 1: & Type 2: & Type 3: & Type 4: \\
\hline \multicolumn{5}{|l|}{ Horsepower } \\
\hline \multicolumn{5}{|l|}{ \# Motors of this type } \\
\hline \multicolumn{5}{|l|}{ Utilization } \\
\hline Other nameplate data & & & & \\
\hline
\end{tabular}

\section{NOTES/DRAWINGS}


Appendix B

Comprehensive List of Cost-Effective Projects Identified from the FEDS Assessment Using Appropriated/Alternative Financed Sources of Capital 


\section{Appendix B-1 \\ Comprehensive List of Cost-Effective Projects Identified from the FEDS Assessment Using Appropriated Sources of Capital}

Table B-1 identifies the 72 cost-effective energy- and cost-reducing retrofit projects identified from the FEDS modeling and analysis based on the assumption that the projects will be funded using appropriated sources of capital funds. Key energy and economic results are presented for each cost-effective retrofit measure. The projects are grouped by building category. More detail, supporting each line-item project recommendation, is contained in the FEDS input and output files, which are delivered to the site energy manager on a CD in conjunction with this report. 
Table B-1 Comprehensive List of Cost-Effective Projects Using Appropriated Sources of Capital

\begin{tabular}{|c|c|c|c|c|c|c|c|}
\hline \multicolumn{2}{|c|}{ FEDS Category } & \multirow{2}{*}{$\begin{array}{l}\qquad \text { Technology Change } \\
\text { Replace LED exit signs with ELECTROLUMINESCENT } \\
\text { PANEL RETRO KIT }\end{array}$} & \multirow{2}{*}{$\begin{array}{c}\begin{array}{c}\text { Energy } \\
\text { Savings } \\
\text { (MMBtu/yr) }\end{array} \\
-\end{array}$} & \multirow{2}{*}{$\begin{array}{c}\text { 1st Year } \\
\text { Savings } \\
\mathbf{( \$ / y r )}\end{array}$} & \multirow{2}{*}{$\begin{array}{c}\text { Installed } \\
\text { Cost (\$) } \\
373\end{array}$} & \multirow{2}{*}{$\begin{array}{c}\begin{array}{c}\text { Net } \\
\text { Present } \\
\text { Value (\$) }\end{array} \\
726\end{array}$} & \multirow{2}{*}{$\begin{array}{l}\text { SIR } \\
2.9\end{array}$} \\
\hline \multirow{10}{*}{87} & $\begin{array}{l}\text { Data Center } \\
\text { Hanger }\end{array}$ & & & & & & \\
\hline & $\begin{array}{l}\text { Data Center } \\
\text { Hanger }\end{array}$ & $\begin{array}{l}\text { Replace LED exit signs with ELECTROLUMINESCENT } \\
\text { PANEL RETRO KIT }\end{array}$ & - & 43 & 248 & 485 & 3.0 \\
\hline & $\begin{array}{l}\text { Data Center } \\
\text { Hanger }\end{array}$ & $\begin{array}{l}\text { Replace existing 2x4 2-tube T8 lighting with 2X4 2-tube } \\
\text { advanced (super) T8 25W with reflector }\end{array}$ & 56 & 3,332 & 30,830 & 24,759 & 1.8 \\
\hline & $\begin{array}{l}\text { Data Center } \\
\text { Hanger }\end{array}$ & $\begin{array}{l}\text { Replace existing 2x4 3-tube T8 lighting with 2X4 3-tube } \\
\text { advanced (super) T8 25W with reflector }\end{array}$ & 149 & 7,757 & 20,702 & 108,889 & 6.3 \\
\hline & $\begin{array}{l}\text { Data Center } \\
\text { Hanger }\end{array}$ & $\begin{array}{l}\text { Replace existing electric water heater with heat pump water } \\
\text { heater }\end{array}$ & 5 & 279 & 428 & 811 & 6.1 \\
\hline & $\begin{array}{l}\text { Data Center } \\
\text { Hanger }\end{array}$ & $\begin{array}{l}\text { Replace existing electric water heater with heat pump water } \\
\text { heater }\end{array}$ & 3 & 129 & 428 & 290 & 2.8 \\
\hline & $\begin{array}{l}\text { Data Center } \\
\text { Hanger }\end{array}$ & Suspended Ceiling: Increase Insulation by R-11 & 236 & 10,357 & 39,520 & 132,810 & 4.4 \\
\hline & $\begin{array}{l}\text { Data Center } \\
\text { Hanger }\end{array}$ & $\begin{array}{l}\text { Replace existing air-cooled chiller with water-cooled } \\
\text { reciprocating electric chiller (very high efficiency) and cooling } \\
\text { tower }\end{array}$ & 780 & 34,689 & 103,186 & 253,913 & 4.7 \\
\hline & $\begin{array}{l}\text { Data Center } \\
\text { Hanger }\end{array}$ & $\begin{array}{l}\text { Replace existing air-cooled chiller with water-cooled } \\
\text { reciprocating electric chiller (very high efficiency) and cooling } \\
\text { tower }\end{array}$ & 584 & 40,805 & 341,513 & 159,622 & 1.7 \\
\hline & \multicolumn{2}{|l|}{ TOTAL } & 1,813 & 97,454 & 537,228 & 682,305 & 2.3 \\
\hline \multirow{4}{*}{167} & storage & $\begin{array}{l}\text { Replace LED exit signs with ELECTROLUMINESCENT } \\
\text { PANEL RETRO KIT }\end{array}$ & 1 & 153 & 932 & 1,710 & 2.8 \\
\hline & storage & $\begin{array}{l}\text { Replace existing 1x8 2-tube T12 lighting with 1X8 2-tube T8 } \\
\text { with reflector }\end{array}$ & 314 & 22,383 & 160,316 & 215,419 & 2.3 \\
\hline & storage & $\begin{array}{l}\text { Replace existing 1x8 2-tube T8 lighting with 2X4 3-tube } \\
\text { advanced (super) T8 lighting }\end{array}$ & 70 & 5,301 & 54,113 & 35,092 & 1.6 \\
\hline & storage & $\begin{array}{l}\text { Service hot water: wrap tank with insulation, insulate pipe near } \\
\text { tank, install aerators, lower tank temperature }\end{array}$ & 3 & 142 & 166 & 658 & 11.9 \\
\hline
\end{tabular}




\begin{tabular}{|c|c|c|c|c|c|c|c|}
\hline \multicolumn{2}{|c|}{ FEDS Category } & \multirow{2}{*}{$\begin{array}{l}\qquad \text { Technology Change } \\
\begin{array}{l}\text { Replace LED exit signs with ELECTROLUMINESCENT } \\
\text { PANEL RETRO KIT }\end{array}\end{array}$} & \multirow{2}{*}{$\begin{array}{c}\begin{array}{c}\text { Energy } \\
\text { Savings } \\
\text { (MMBtu/yr) }\end{array} \\
2\end{array}$} & \multirow{2}{*}{$\begin{array}{c}\begin{array}{c}\text { 1st Year } \\
\text { Savings } \\
\text { (\$/yr) }\end{array} \\
224\end{array}$} & \multirow{2}{*}{$\begin{array}{c}\text { Installed } \\
\text { Cost (\$) }\end{array}$} & \multirow{2}{*}{$\begin{array}{c}\begin{array}{c}\text { Net } \\
\text { Present } \\
\text { Value (\$) }\end{array} \\
2,589\end{array}$} & \multirow{2}{*}{$\begin{array}{l}\text { SIR } \\
3.1\end{array}$} \\
\hline & $\begin{array}{l}\text { Admin/control } \\
\text { room }\end{array}$ & & & & & & \\
\hline & $\begin{array}{l}\text { Admin/control } \\
\text { room }\end{array}$ & $\begin{array}{l}\text { Replace LED exit signs with ELECTROLUMINESCENT } \\
\text { PANEL RETRO KIT }\end{array}$ & - & 26 & 140 & 273 & 3.0 \\
\hline & $\begin{array}{l}\text { Admin/control } \\
\text { room }\end{array}$ & $\begin{array}{l}\text { Replace existing 2x4 4-tube T8 lighting with 2X4 3-tube } \\
\text { advanced (super) T8 25W with reflector }\end{array}$ & 392 & 14,946 & 50,912 & 198,730 & 4.9 \\
\hline & $\begin{array}{l}\text { Admin/control } \\
\text { room }\end{array}$ & $\begin{array}{l}\text { Replace existing 2x4 4-tube T8 lighting with 2X4 3-tube } \\
\text { advanced (super) T8 25W with reflector }\end{array}$ & 43 & 1,712 & 5,990 & 22,599 & 4.8 \\
\hline & $\begin{array}{l}\text { Admin/control } \\
\text { room }\end{array}$ & $\begin{array}{l}\text { Replace existing 1x8 2-tube T8 lighting with 2X4 3-tube } \\
\text { advanced (super) T8 lighting }\end{array}$ & 553 & 23,186 & 149,392 & 239,384 & 2.6 \\
\hline & $\begin{array}{l}\text { Admin/control } \\
\text { room }\end{array}$ & $\begin{array}{l}\text { Replace existing 2x4 2-tube T8 lighting with 2X4 2-tube } \\
\text { advanced (super) T8 25W with reflector }\end{array}$ & 297 & 9,254 & 29,289 & 124,986 & 5.3 \\
\hline & $\begin{array}{l}\text { Admin/control } \\
\text { room }\end{array}$ & $\begin{array}{l}\text { Replace existing 2x4 3-tube T8 lighting with 2X4 3-tube } \\
\text { advanced (super) T8 25W with reflector }\end{array}$ & 340 & 12,398 & 67,702 & 138,990 & 3.1 \\
\hline & $\begin{array}{l}\text { Admin/control } \\
\text { room }\end{array}$ & $\begin{array}{l}\text { Replace existing electric water heater with heat pump water } \\
\text { heater and install aerators }\end{array}$ & 48 & 2,890 & 3,466 & 12,719 & 7.7 \\
\hline & $\begin{array}{l}\text { Admin/control } \\
\text { room }\end{array}$ & Suspended Ceiling: Increase Insulation by R-19 & 1,171 & 22,551 & 147,235 & 227,995 & 2.5 \\
\hline & $\begin{array}{l}\text { Admin/control } \\
\text { room }\end{array}$ & $\begin{array}{l}\text { Service hot water: Wrap Tank with Insulation, Insulate Pipe } \\
\text { Near Tank, Aerators, Lower Tank Temperature }\end{array}$ & 1 & 58 & 128 & 248 & 6.3 \\
\hline & \multicolumn{2}{|l|}{ TOTAL } & 3,235 & 115,224 & 671,039 & $1,221,392$ & 2.8 \\
\hline \multirow{7}{*}{440} & East Wing & Replace 3-lamp T-8s with 2-lamp super T-8s & 46 & 2553 & 13267 & 31182 & 3.4 \\
\hline & East Wing & $\begin{array}{l}\text { Replace LED exit signs with ELECTROLUMINESCENT } \\
\text { PANEL RETRO KIT }\end{array}$ & 1 & 107 & 640 & 1219 & 2.9 \\
\hline & East Wing & $\begin{array}{l}\text { Add } 4 \text { inches fiberglass insulation to interior surface of metal } \\
\text { roof }\end{array}$ & 129 & 7310 & 26665 & 100630 & 4.8 \\
\hline & Cooled Center & Replace 3-lamp T-8s with 2-lamp super T-8s & 86 & 4692 & 24301 & 57397 & 3.4 \\
\hline & $\begin{array}{l}\text { Cooled Center } \\
\text { Admin }\end{array}$ & $\begin{array}{l}\text { Replace LED exit signs with ELECTROLUMINESCENT } \\
\text { PANEL RETRO KIT }\end{array}$ & 0 & 54 & 320 & 610 & 2.9 \\
\hline & $\begin{array}{l}\text { Cooled Center } \\
\text { Shops }\end{array}$ & $\begin{array}{l}\text { Replace LED exit signs with ELECTROLUMINESCENT } \\
\text { PANEL RETRO KIT }\end{array}$ & 0 & 54 & 320 & 610 & 2.9 \\
\hline & Cooled Center & Add 4 inches fiberglass insulation to interior surface of metal & 460 & 27245 & 97683 & 376746 & 4.9 \\
\hline
\end{tabular}




\begin{tabular}{|c|c|c|c|c|c|c|c|}
\hline \multicolumn{2}{|c|}{ FEDS Category } & \multirow{2}{*}{ Technology Change } & \multirow{2}{*}{$\begin{array}{c}\text { Energy } \\
\text { Savings } \\
\text { (MMBtu/yr) }\end{array}$} & \multirow{2}{*}{$\begin{array}{c}\text { 1st Year } \\
\text { Savings } \\
(\$ / y r)\end{array}$} & \multirow{2}{*}{$\begin{array}{c}\text { Installed } \\
\text { Cost (\$) }\end{array}$} & \multirow{2}{*}{$\begin{array}{c}\text { Net } \\
\text { Present } \\
\text { Value (\$) }\end{array}$} & \multirow{2}{*}{ SIR } \\
\hline & & & & & & & \\
\hline & A Wing & $\begin{array}{l}\text { Replace air-cooled chiller with water-cooled chiller and cooling } \\
\text { tower }\end{array}$ & 87 & 7907 & 81877 & 2333 & 1.4 \\
\hline & $\begin{array}{l}\text { A Wing } \\
\text { Admin }\end{array}$ & Replace 32W T-8s with 25W super T-8s & 48 & 2567 & 21131 & 23574 & 2.1 \\
\hline & $\begin{array}{l}\text { A Wing } \\
\text { Admin }\end{array}$ & $\begin{array}{l}\text { Replace LED exit signs with ELECTROLUMINESCENT } \\
\text { PANEL RETRO KIT }\end{array}$ & 1 & 161 & 960 & 1829 & 2.9 \\
\hline & $\begin{array}{l}\text { A Wing } \\
\text { Shops }\end{array}$ & Replace 32W T-8s with 25W super T-8s & 39 & 2170 & 14707 & 23076 & 2.6 \\
\hline & $\begin{array}{l}\text { A Wing } \\
\text { Shops }\end{array}$ & $\begin{array}{l}\text { Replace LED exit signs with ELECTROLUMINESCENT } \\
\text { PANEL RETRO KIT }\end{array}$ & 1 & 161 & 960 & 1829 & 2.9 \\
\hline & A Wing & Increase insulation by R-19 above suspended ceiling & 101 & 5121 & 42186 & 46988 & 2.1 \\
\hline & $\begin{array}{l}\text { Uncooled A } \\
\text { Wing }\end{array}$ & Replace 4-lamp 32W T-8s with 3-lamp 30W super T-8s & 10 & 564 & 3978 & 5840 & 2.5 \\
\hline & $\begin{array}{l}\text { Uncooled A } \\
\text { Wing }\end{array}$ & $\begin{array}{l}\text { Replace LED exit signs with ELECTROLUMINESCENT } \\
\text { PANEL RETRO KIT }\end{array}$ & 0 & 52 & 320 & 578 & 2.8 \\
\hline & $\begin{array}{l}\text { Uncooled } \\
\text { Center }\end{array}$ & $\begin{array}{l}\text { Replace LED exit signs with ELECTROLUMINESCENT } \\
\text { PANEL RETRO KIT }\end{array}$ & 0 & 52 & 320 & 578 & 2.8 \\
\hline & \multicolumn{2}{|l|}{ TOTAL } & 1009 & 60770 & 329635 & 675019 & 3.0 \\
\hline \multirow{7}{*}{475} & $\begin{array}{l}\text { Admin/data } \\
\text { center }\end{array}$ & $\begin{array}{l}\text { Replace LED exit signs with ELECTROLUMINESCENT } \\
\text { PANEL RETRO KIT }\end{array}$ & 1 & 246 & 1,398 & 2,843 & 3.0 \\
\hline & $\begin{array}{l}\text { Admin/data } \\
\text { center }\end{array}$ & $\begin{array}{l}\text { Replace LED exit signs with ELECTROLUMINESCENT } \\
\text { PANEL RETRO KIT }\end{array}$ & - & 82 & 466 & 947 & 3.0 \\
\hline & $\begin{array}{l}\text { Admin/data } \\
\text { center }\end{array}$ & $\begin{array}{l}\text { Replace existing 2x4 2-tube T8 lighting with } 2 \text { X4 2-tube } \\
\text { advanced (super) T8 25W with reflector }\end{array}$ & 866 & 40,857 & 164,429 & 514,673 & 4.1 \\
\hline & $\begin{array}{l}\text { Admin/data } \\
\text { center }\end{array}$ & $\begin{array}{l}\text { Replace existing 2x4 2-tube T8 lighting with 2X4 2-tube } \\
\text { advanced (super) T8 25W with reflector }\end{array}$ & 226 & 12,212 & 54,810 & 149,172 & 3.7 \\
\hline & $\begin{array}{l}\text { Admin/data } \\
\text { center }\end{array}$ & $\begin{array}{l}\text { Replace existing electric water heater with heat pump water } \\
\text { heater }\end{array}$ & 14 & 789 & 6,426 & 480 & 1.1 \\
\hline & $\begin{array}{l}\text { Admin/data } \\
\text { center }\end{array}$ & $\begin{array}{l}\text { Replace existing electric water heater with heat pump water } \\
\text { heater }\end{array}$ & 6 & 313 & 1,285 & 885 & 2.3 \\
\hline & Admin/data & Replace existing air-cooled chiller with water-cooled & 1,881 & 83,890 & 545,818 & 443,733 & 2.1 \\
\hline
\end{tabular}




\begin{tabular}{|c|c|c|c|c|c|c|c|}
\hline \multicolumn{2}{|c|}{ FEDS Category } & \multirow{2}{*}{$\begin{array}{l}\qquad \text { Technology Change } \\
\qquad \begin{array}{l}\text { reciprocating electric chiller (very high efficiency) and cooling } \\
\text { tower }\end{array}\end{array}$} & \multirow{2}{*}{$\begin{array}{c}\text { Energy } \\
\text { Savings } \\
\text { (MMBtu/yr) }\end{array}$} & \multirow{2}{*}{$\begin{array}{c}\text { 1st Year } \\
\text { Savings } \\
(\$ / y r)\end{array}$} & \multirow{2}{*}{$\begin{array}{c}\text { Installed } \\
\text { Cost (\$) }\end{array}$} & \multirow{2}{*}{$\begin{array}{c}\text { Net } \\
\text { Present } \\
\text { Value (\$) }\end{array}$} & \multirow[t]{2}{*}{ SIR } \\
\hline & center & & & & & & \\
\hline & storage & $\begin{array}{l}\text { Replace LED exit signs with ELECTROLUMINESCENT } \\
\text { PANEL RETRO KIT }\end{array}$ & 1 & 309 & 1,864 & 3,463 & 2.9 \\
\hline & storage & $\begin{array}{l}\text { Replace existing 2x4 3-tube T8 lighting with 2X4 2-tube } \\
\text { advanced (super) T8 32W with reflector }\end{array}$ & 574 & 35,800 & 126,334 & 473,136 & 4.7 \\
\hline & storage & $\begin{array}{l}\text { Replace } 400 \mathrm{~W} \text { metal halide lighting with } 310 \mathrm{~W} \text { high pressure } \\
\text { sodium }\end{array}$ & 21 & 815 & 4,422 & 9,011 & 3.0 \\
\hline & TOTAL & & 3,590 & 175,313 & 907,252 & $1,598,343$ & 2.8 \\
\hline \multirow{13}{*}{631} & NEX & Replace 75W Incandescent light with 18W CFL & 182 & 12,285 & 1,448 & 205,235 & 142.7 \\
\hline & NEX & $\begin{array}{l}\text { Replace LED exit signs with ELECTROLUMINESCENT } \\
\text { PANEL RETRO KIT }\end{array}$ & 2 & 483 & 2,795 & 5,523 & 3.0 \\
\hline & NEX & $\begin{array}{l}\text { Replace existing 2x4 2-tube T8 lighting with 2X4 2-tube } \\
\text { advanced (super) T8 25W with reflector }\end{array}$ & 1,989 & 105,041 & 475,490 & $1,278,087$ & 3.7 \\
\hline & NEX & $\begin{array}{l}\text { Replace existing electric water heater with heat pump water } \\
\text { heater }\end{array}$ & 275 & 14,340 & 10,318 & 56,699 & 12.9 \\
\hline & Food Court & $\begin{array}{l}\text { Replace LED exit signs with ELECTROLUMINESCENT } \\
\text { PANEL RETRO KIT }\end{array}$ & 1 & 169 & 932 & 1,983 & 3.1 \\
\hline & Food Court & $\begin{array}{l}\text { Replace existing 2x4 2-tube T8 lighting with 2X4 2-tube } \\
\text { advanced (super) T8 25W with reflector }\end{array}$ & 305 & 14,514 & 52,295 & 189,094 & 4.6 \\
\hline & Food Court & $\begin{array}{l}\text { Replace existing propane water heater with heat pump water } \\
\text { heater }\end{array}$ & 13 & 256 & 514 & 522 & 4.6 \\
\hline & Food Court & $\begin{array}{l}\text { Replace existing propane water heater with heat pump water } \\
\text { heater }\end{array}$ & 13 & 256 & 514 & 522 & 4.6 \\
\hline & Food Court & $\begin{array}{l}\text { Replace existing propane water heater with heat pump water } \\
\text { heater }\end{array}$ & 13 & 256 & 514 & 522 & 4.6 \\
\hline & Food Court & $\begin{array}{l}\text { Replace existing propane water heater with heat pump water } \\
\text { heater }\end{array}$ & 13 & 256 & 514 & 522 & 4.6 \\
\hline & Food Court & $\begin{array}{l}\text { Replace existing propane water heater with heat pump water } \\
\text { heater }\end{array}$ & 13 & 256 & 514 & 522 & 4.6 \\
\hline & Food Court & Suspended Ceiling: Increase Insulation by R-19 & 61 & 4,158 & 60,272 & 8,903 & 1.1 \\
\hline & \multicolumn{2}{|l|}{ TOTAL } & 2,880 & 152,270 & 606,120 & $1,748,134$ & 3.9 \\
\hline
\end{tabular}




\begin{tabular}{|c|c|c|c|c|c|c|c|}
\hline \multicolumn{2}{|c|}{ FEDS Category } & \multirow{2}{*}{$\begin{array}{l}\qquad \text { Technology Change } \\
\begin{array}{l}\text { Replace LED exit signs with ELECTROLUMINESCENT } \\
\text { PANEL RETRO KIT }\end{array}\end{array}$} & \multirow{2}{*}{$\begin{array}{c}\begin{array}{c}\text { Energy } \\
\text { Savings } \\
\text { (MMBtu/yr) }\end{array} \\
1\end{array}$} & \multirow{2}{*}{$\begin{array}{c}\begin{array}{c}\text { 1st Year } \\
\text { Savings } \\
\text { (\$/yr) }\end{array} \\
108\end{array}$} & \multirow{2}{*}{$\begin{array}{c}\text { Installed } \\
\text { Cost (\$) } \\
621\end{array}$} & \multirow{2}{*}{$\begin{array}{c}\begin{array}{c}\text { Net } \\
\text { Present } \\
\text { Value (\$) }\end{array} \\
1,257\end{array}$} & \multirow{2}{*}{$\begin{array}{l}\text { SIR } \\
3.0\end{array}$} \\
\hline \multirow{11}{*}{1670} & 1-story admin & & & & & & \\
\hline & 1-story admin & $\begin{array}{l}\text { Replace existing 2x4 2-tube T8 lighting with 2X4 2-tube } \\
\text { advanced (super) T8 25W with reflector }\end{array}$ & 37 & 2,086 & 22,198 & 12,593 & 1.6 \\
\hline & 1-story admin & $\begin{array}{l}\text { Replace existing air-cooled chiller with water-cooled } \\
\text { reciprocating electric chiller (very high efficiency) and cooling } \\
\text { tower }\end{array}$ & 88 & 4,829 & 45,111 & 14,811 & 1.5 \\
\hline & 2-story shops & $\begin{array}{l}\text { Replace LED exit signs with ELECTROLUMINESCENT } \\
\text { PANEL RETRO KIT }\end{array}$ & 2 & 328 & 1,864 & 3,793 & 3.0 \\
\hline & 2-story shops & $\begin{array}{l}\text { Replace existing 2x4 2-tube T8 lighting with 2X4 2-tube } \\
\text { advanced (super) T8 25W with reflector }\end{array}$ & 435 & 20,938 & 103,038 & 245,123 & 3.4 \\
\hline & 2-story shops & $\begin{array}{l}\text { Replace } 250 \mathrm{~W} \text { metal halide lighting with } 2 \text { x3 6-tube biaxial } \\
\text { lighting with reflector }\end{array}$ & 42 & 2,564 & 15,327 & 27,826 & 2.8 \\
\hline & 2-story shops & $\begin{array}{l}\text { Replace existing air-cooled chiller with water-cooled } \\
\text { reciprocating chiller (very high efficiency) and cooling tower }\end{array}$ & 473 & 25,822 & 137,260 & 148,869 & 2.6 \\
\hline & 2-story shops & $\begin{array}{l}\text { Service hot water: rap Tank with Insulation, Insulate Pipe Near } \\
\text { Tank, Low flow shower heads, Aerators, Lower Tank } \\
\text { Temperature }\end{array}$ & 27 & 1,331 & 1,581 & 6,154 & 11.7 \\
\hline & $\begin{array}{l}1 \text { story high } \\
\text { bay }\end{array}$ & $\begin{array}{l}\text { Replace LED exit signs with ELECTROLUMINESCENT } \\
\text { PANEL RETRO KIT }\end{array}$ & - & 102 & 621 & 1,161 & 2.9 \\
\hline & $\begin{array}{l}1 \text { story high } \\
\text { bay }\end{array}$ & $\begin{array}{l}\text { Replace } 400 \mathrm{~W} \text { metal halide lighting with } 310 \mathrm{~W} \text { high pressure } \\
\text { sodium }\end{array}$ & 72 & 4,271 & 45,479 & 25,847 & 1.6 \\
\hline & \multicolumn{2}{|l|}{ TOTAL } & 1,177 & 62,379 & 373,100 & 487,434 & 2.3 \\
\hline
\end{tabular}




\section{Appendix B-2 \\ Comprehensive List of Cost-Effective Projects Identified from the FEDS Assessment Using Alternative Financing Sources of Capital}

Table B-2 identifies the 38 cost-effective energy- and cost-reducing retrofit projects identified from the FEDS modeling and analysis based on the assumption that they will be funded using alternative financing source of capital funds. Alternative financing includes UESC and ESPC, as well as any other third party financing. Key energy and economic results are presented for each cost-effective retrofit measure. The projects are grouped by building category. 
Table B-2 Comprehensive List of Cost-Effective Projects Using Alternative Financing Sources of Capital

\begin{tabular}{|c|c|c|c|c|c|c|c|}
\hline \multicolumn{2}{|c|}{ FEDS Category } & \multirow{2}{*}{$\begin{array}{l}\text { Technology Change } \\
\qquad \begin{array}{l}\text { Replace air-cooled chillers with water-cooled reciprocating electric chiller } \\
\text { (very high efficiency) and cooling tower }\end{array} \\
\end{array}$} & \multirow{2}{*}{$\begin{array}{c}\begin{array}{c}\text { Energy } \\
\text { Savings } \\
\text { (MMMBtu/yr) }\end{array} \\
879\end{array}$} & \multirow{2}{*}{$\begin{array}{c}\begin{array}{c}\text { 1st Year } \\
\text { Savings } \\
\text { (\$/yr) }\end{array} \\
30,223\end{array}$} & \multirow{2}{*}{$\begin{array}{c}\text { Installed } \\
\text { Cost (\$) } \\
120,226\end{array}$} & \multirow{2}{*}{$\begin{array}{c}\text { Net } \\
\text { Present } \\
\text { Value (\$) }\end{array}$} & \multirow{2}{*}{$\begin{array}{r}\text { SIR } \\
2.0\end{array}$} \\
\hline \multirow{6}{*}{87} & \multirow{5}{*}{ Data Center } & & & & & & \\
\hline & & Replace electric water heater with heat pump water heater & 5 & 98 & 497 & 1,100 & 3.2 \\
\hline & & Replace electric water heater with heat pump water heater & 3 & 101 & 497 & 243 & 1.5 \\
\hline & & $\begin{array}{l}\text { Replace existing 2x4 3-tube T8 with 2X4 3-tube advanced (super) 25W T8 } \\
\text { with reflector }\end{array}$ & 154 & 5,717 & 24,014 & 20,875 & 1.9 \\
\hline & & Suspended Ceiling: Increase Insulation by R-11 & 1,066 & 44,547 & 45,843 & 311,198 & 7.8 \\
\hline & \multicolumn{2}{|l|}{ TOTAL } & 2,107 & 80,686 & 191,077 & 455,442 & 3.4 \\
\hline \multirow{10}{*}{167} & \multirow{8}{*}{$\begin{array}{l}\text { Admin/control } \\
\text { room }\end{array}$} & Replace existing 1x8 2-tube T8 with 2X4 3-tube advanced (super) T8 & 549 & 11,854 & 173,294 & 2,304 & 1.0 \\
\hline & & $\begin{array}{l}\text { Replace existing 2x4 2-tube T8 with 2X4 2-tube advanced (super) 25W T8 } \\
\text { with reflector }\end{array}$ & 294 & 7,202 & 33,975 & 18,079 & 1.5 \\
\hline & & $\begin{array}{l}\text { Replace existing 2x4 3-tube T8 with 2X4 3-tube advanced (super) 25W T8 } \\
\text { with reflector }\end{array}$ & 337 & 7,282 & 78,535 & 16,259 & 1.2 \\
\hline & & $\begin{array}{l}\text { Replace existing 2x4 4-tube T8 lighting with } 2 \text { X4 3-tube advanced (super) T8 } \\
\text { with reflector }\end{array}$ & 389 & 8,410 & 59,058 & 43,739 & 1.7 \\
\hline & & $\begin{array}{l}\text { Replace existing 2x4 4-tube T8 lighting with 2X4 3-tube advanced (super) T8 } \\
\text { with reflector }\end{array}$ & 43 & 948 & 6,948 & 4,880 & 1.7 \\
\hline & & $\begin{array}{l}\text { Replace LED exit signs with ELECTROLUMINESCENT PANEL RETRO } \\
\text { KIT }\end{array}$ & 2 & 44 & 1,459 & 16 & 1.0 \\
\hline & & Replace propane water heater with heat pump water heater plus misc. measures & 48 & 1,127 & 4,020 & 12,552 & 4.1 \\
\hline & & Service hot water: Install faucet aerators, lower tank temperature & 1 & 33 & 19 & 231 & 13.4 \\
\hline & storage & Service hot water: Install faucet aerators, lower tank temperature & 2 & 57 & 63 & 667 & 11.5 \\
\hline & \multicolumn{2}{|l|}{ TOTAL } & 1,665 & 36,957 & 357,371 & 98,727 & 1.3 \\
\hline \multirow{3}{*}{440} & East Wing & Replace 3-lamp T-8s with 2-lamp super T-8s & 47 & 2,606 & 13,267 & 2,746 & 1.2 \\
\hline & East Wing & $\begin{array}{l}\text { Replace LED exit signs with ELECTROLUMINESCENT PANEL RETRO } \\
\text { KIT }\end{array}$ & 1 & 122 & 640 & 108 & 1.2 \\
\hline & East Wing & Add 4 inches fiberglass insulation to interior surface of metal roof & 130 & 7,815 & 26,665 & 21,356 & 1.8 \\
\hline
\end{tabular}




\begin{tabular}{|c|c|c|c|c|c|c|c|}
\hline \multicolumn{2}{|c|}{ FEDS Category } & \multirow{2}{*}{$\begin{array}{l}\text { Technology Change } \\
\text { Replace existing packaged DX AC with higher efficiency unit }\end{array}$} & \multirow{2}{*}{$\begin{array}{c}\begin{array}{c}\text { Energy } \\
\text { Savings } \\
\text { (MMMBtu/yr) }\end{array} \\
32 \\
\end{array}$} & \multirow{2}{*}{$\begin{array}{c}\begin{array}{c}\text { 1st Year } \\
\text { Savings } \\
\text { (\$/yr) }\end{array} \\
6,132 \\
\end{array}$} & \multirow{2}{*}{$\begin{array}{c}\begin{array}{c}\text { Installed } \\
\text { Cost (\$) }\end{array} \\
35,326 \\
\end{array}$} & \multirow{2}{*}{$\begin{array}{c}\begin{array}{c}\text { Net } \\
\text { Present } \\
\text { Value (\$) }\end{array} \\
2,352 \\
\end{array}$} & \multirow{2}{*}{$\begin{array}{l}\text { SIF } \\
1.1\end{array}$} \\
\hline & Cooled Center & & & & & & \\
\hline & $\begin{array}{l}\text { Cooled Center } \\
\text { Admin }\end{array}$ & Replace 3-lamp T-8s with 2-lamp super T-8s & 84 & 4704 & 24301 & 4602 & 1.2 \\
\hline & $\begin{array}{l}\text { Cooled Center } \\
\text { Admin }\end{array}$ & $\begin{array}{l}\text { Replace LED exit signs with ELECTROLUMINESCENT PANEL RETRO } \\
\text { KIT }\end{array}$ & 0 & 61 & 320 & 53 & 1.2 \\
\hline & $\begin{array}{l}\text { Cooled Center } \\
\text { Shops }\end{array}$ & $\begin{array}{l}\text { Replace LED exit signs with ELECTROLUMINESCENT PANEL RETRO } \\
\text { KIT }\end{array}$ & 0 & 61 & 320 & 53 & 1.2 \\
\hline & Cooled Center & Add 4 inches fiberglass insulation to interior surface of metal roof & 426 & 26825 & 97683 & 67147 & 1.7 \\
\hline & Cooled A Wing & $\begin{array}{l}\text { Replace LED exit signs with ELECTROLUMINESCENT PANEL RETRO } \\
\text { KIT }\end{array}$ & 1 & 185 & 960 & 179 & 1.2 \\
\hline & Cooled A Wing & $\begin{array}{l}\text { Replace LED exit signs with ELECTROLUMINESCENT PANEL RETRO } \\
\text { KIT }\end{array}$ & 1 & 185 & 960 & 179 & 1.2 \\
\hline & Cooled A Wing & Increase insulation by R-11 above suspended ceiling & 97 & 5405 & 32271 & 938 & 1 \\
\hline & $\begin{array}{l}\text { Uncooled A } \\
\text { Wing }\end{array}$ & $\begin{array}{l}\text { Replace LED exit signs with ELECTROLUMINESCENT PANEL RETRO } \\
\text { KIT }\end{array}$ & 0 & 57 & 320 & 33 & 1.1 \\
\hline & Uncooled Center & $\begin{array}{l}\text { Replace LED exit signs with ELECTROLUMINESCENT PANEL RETRO } \\
\text { KIT }\end{array}$ & 0 & 57 & 320 & 33 & 1.1 \\
\hline & \multicolumn{2}{|l|}{ TOTAL } & 819 & 54,215 & 233,353 & 99,779 & 1.4 \\
\hline \multirow{8}{*}{475} & \multirow{5}{*}{$\begin{array}{l}\text { Admin/data } \\
\text { center }\end{array}$} & Replace electric water heater with heat pump water heater & 6 & 168 & 1,491 & 307 & 1.2 \\
\hline & & $\begin{array}{l}\text { Replace existing 2x4 2-tube T8 with 2X4 2-tube advanced (super) 25W T8 } \\
\text { with reflector }\end{array}$ & 896 & 33,264 & 190,738 & 68,844 & 1.4 \\
\hline & & $\begin{array}{l}\text { Replace existing 2x4 2-tube T8 with 2X4 2-tube advanced (super) 25W T8 } \\
\text { with reflector }\end{array}$ & 233 & 8,347 & 63,579 & 7,066 & 1.1 \\
\hline & & $\begin{array}{l}\text { Replace LED exit signs with ELECTROLUMINESCENT PANEL RETRO } \\
\text { KIT }\end{array}$ & 1 & 49 & 1,621 & 12 & 1.0 \\
\hline & & $\begin{array}{l}\text { Replace LED exit signs with ELECTROLUMINESCENT PANEL RETRO } \\
\text { KIT }\end{array}$ & $<1$ & 16 & 540 & 4 & 1.0 \\
\hline & \multirow[t]{2}{*}{ storage } & $\begin{array}{l}\text { Replace existing 2x4 3-tube T8 lighting with 2X4 2-tube advanced (super) T8 } \\
\text { with reflector }\end{array}$ & 574 & 17,040 & 146,548 & 88,160 & 1.6 \\
\hline & & Replace existing 400W MH lighting with 310W HPS lighting & 21 & 769 & 5,129 & 855 & 1.2 \\
\hline & \multicolumn{2}{|l|}{ TOTAL } & 1,731 & 59,653 & 409,646 & 165,248 & 1.4 \\
\hline 631 & NEX Food Court & Replace existing 2x4 2-tube T8 with 2X4 2-tube advanced (super) 25W T8 & 305 & 11,403 & 60,662 & 30,816 & 1.5 \\
\hline
\end{tabular}




\begin{tabular}{|c|c|c|c|c|c|c|c|}
\hline \multicolumn{2}{|c|}{ FEDS Category } & \multirow{2}{*}{ Technology Change } & \multirow{2}{*}{$\begin{array}{c}\text { Energy } \\
\text { Savings } \\
\text { (MMMBtu/yr) }\end{array}$} & \multirow{2}{*}{$\begin{array}{c}\text { 1st Year } \\
\text { Savings } \\
(\$ / y r)\end{array}$} & \multirow{2}{*}{$\begin{array}{l}\text { Installed } \\
\text { Cost (\$) }\end{array}$} & \multirow{2}{*}{$\begin{array}{c}\text { Net } \\
\text { Present } \\
\text { Value (\$) }\end{array}$} & \multirow[t]{2}{*}{ SIR } \\
\hline & & & & & & & \\
\hline & & $\begin{array}{l}\text { Replace LED exit signs with ELECTROLUMINESCENT PANEL RETRO } \\
\text { KIT }\end{array}$ & 1 & 36 & 1,081 & 35 & 1.0 \\
\hline & & Replace propane water heater with heat pump water heater & 13 & 290 & 596 & 1,349 & 3.3 \\
\hline & & Replace propane water heater with heat pump water heater & 13 & 290 & 596 & 1,349 & 3.3 \\
\hline & & Replace propane water heater with heat pump water heater & 13 & 290 & 596 & 1,349 & 3.3 \\
\hline & & Replace propane water heater with heat pump water heater & 13 & 290 & 596 & 1,349 & 3.3 \\
\hline & & Replace propane water heater with heat pump water heater & 13 & 290 & 596 & 1,349 & 3.3 \\
\hline & \multirow{5}{*}{ NEX } & $\begin{array}{l}\text { Replace existing 2x4 2-tube T8 with 2X4 2-tube advanced (super) 25W T8 } \\
\text { with reflector }\end{array}$ & 2,286 & 83,491 & 551,569 & 152,826 & 1.3 \\
\hline & & Replace existing 40W INC spot with 11W CFL & 241 & 8,946 & 2,805 & 95,741 & 35.1 \\
\hline & & Replace existing 75W INC with 18W CFL & 210 & 7,294 & 1,680 & 77,923 & 47.4 \\
\hline & & $\begin{array}{l}\text { Replace LED exit signs with ELECTROLUMINESCENT PANEL RETRO } \\
\text { KIT }\end{array}$ & 3 & 100 & 3,243 & 58 & 1.0 \\
\hline & & Replace propane water heater with heat pump water heater plus misc. measures & 275 & 8,604 & 11,969 & 70,317 & 6.9 \\
\hline & \multicolumn{2}{|l|}{ TOTAL } & 3,386 & 121,324 & 635,989 & 434,461 & 1.7 \\
\hline \multirow{6}{*}{1670} & 1 story Admin & $\begin{array}{l}\text { Replace LED exit signs with ELECTROLUMINESCENT PANEL RETRO } \\
\text { KIT }\end{array}$ & 1 & 23 & 721 & 18 & 1.0 \\
\hline & \multirow{4}{*}{ 2-story } & Replace existing 250W MH lighting with 6-tube biaxial lighting with reflector & 47 & 1,873 & 17,779 & 874 & 1.0 \\
\hline & & $\begin{array}{l}\text { Replace existing 2x4 2-tube T8 with 2X4 2-tube advanced (super) 25W T8 } \\
\text { with reflector }\end{array}$ & 483 & 17,840 & 119,525 & 57,486 & 1.5 \\
\hline & & $\begin{array}{l}\text { Replace LED exit signs with ELECTROLUMINESCENT PANEL RETRO } \\
\text { KIT }\end{array}$ & 2 & 70 & 2,162 & 65 & 1.0 \\
\hline & & Service hot water: Iinstall LFSHs, Aerators, Lower Tank Temperature & 24 & 805 & 861 & 6,139 & 8.1 \\
\hline & \multicolumn{2}{|l|}{ TOTAL } & 557 & 20,611 & 141,048 & 64,582 & 1.5 \\
\hline
\end{tabular}


Appendix C

\section{Building Details}




\section{Appendix C \\ Energy Conservation Measures for Pearl Harbor Buildings}

The following sections describe in detail the cost-effective retrofit projects for the six buildings visited by PNNL. Energy consumption by fuel type and building energy system are presented along with the direct and indirect (e.g., at the utility power plant for electricity consumption) emissions impacts. The figures presented are for the case of appropriated funding.

\section{Building 87 Data Center}

Building 87 is a 53,724 $\mathrm{ft}^{2}$ data center built inside an historic hanger on Ford Island at Pearl Harbor Naval Base. The building is a wood frame construction connected to existing concrete walls inside the hanger. The ceiling of the data center is connected to the metal structure of the original hanger leaving a very tall open space above the data center ceiling and the existing hanger roof.

The building has a large server room (approximately 8,600 $\mathrm{ft}^{2}$ ), in addition to general office space. The building also has a 24/7 control and dispatch room, which was inaccessible during the auditing team's visit. The hanger doors on the southwest end opens to a $6,000 \mathrm{ft}^{2}$ high bay space that is the full height of the existing hanger. This space is not conditioned.

Cooling is provided by a 60-ton air-cooled chiller providing chilled water to air-handling units in the building. The server space, electrical room, and uninterruptible power supply (UPS) room are cooled with 11 Liebert air-cooled chillers. These were installed in 2001 and provide approximately 250 tons of cooling. Because of the sensitive computer systems, climate control is continuous and operates within a narrow band.

The largest single load in the building is the computers in the data center. The data center is served by 2, 750-kVA UPS systems. During the site visit, these were showing loads between 155 - $166 \mathrm{kVA}$ and 179 - $187 \mathrm{kVA}$, respectively.

The predominant lighting type (approximately 75\%) is 2-tube F32T8 lighting installed in $2 \times 4$ fixtures in the suspended ceiling. Hallways and admin spaces have 2x2 fixtures with 2-tube F32T8U U-type lamps. The open high-bay space has eight 400-watt metal halide fixtures.

The building has one 10-gallon electric hot water heater in the kitchen area. 


\section{Energy Consumption by Fuel Type}

The actual metered energy consumption for FY2009 was 5,454,720 kWh. The modeled energy consumption for a typical year was 5,445,574 kWh before retrofits and 4,554,094 kWh after proposed retrofits are implemented. The energy use intensity goes from 619.5 MMBtu/Ksf to 518.1 MMBtu/Ksf after retrofits.

Annual Energy Use by Building Set and Fuel Type

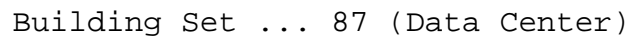

Fuel

Energy

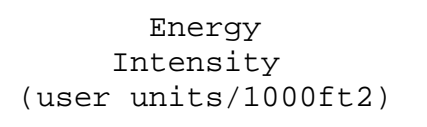

Energy

Dollars

(user units/1000ft2) (MMBtu/1000ft2)

$(2009)^{*}$

Electricity (kWh)

existing

post-retrofit

difference

$5,445,574$

$181,519.1$
$151,803.1$
$-29,716.0$

$4,554,094$
$-891,480$

$-29,716$.

619.5
518.1
-101.4
-16

930,039

773,290

$\%$ change

$-16$

16

Total (MMBtu)

existing

post-retrofit

difference

$$
\begin{aligned}
& 18,586 \\
& 15,543 \\
& -3,043
\end{aligned}
$$

619.5

518.1

-101.4
-16

619.5

518.1

$-101.4$

$-16$

$-156,748$
-17

* Dollar values for electricity include both energy and demand components. 


\section{Energy Consumption by End Uses}

During a typical year, the computer loads are the largest energy user with over 2,960 MWh/ year, followed by cooling with 1,624 MWh/year.

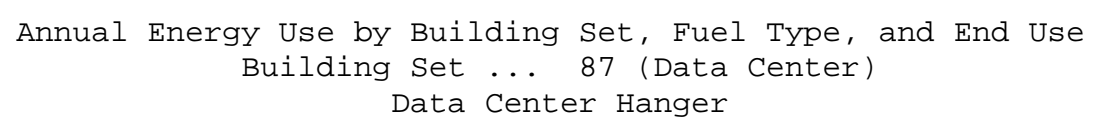

Fuel
Electricity (kWh)
existing
post-retrofit
difference
$\%$ change
Total (MMBtu)
existing
post-retrofit
difference
$\%$ change

$\begin{array}{rrrr}\text { Cooling } & \text { Vent } & \text { Lights } \\ & & & \\ \odot & 1,624,274 & 659,145 & 199,426 \\ \odot & 785,607 & 659,145 & 148,759 \\ \odot & -838,667 & \odot & -50,667 \\ \odot & -52 & \odot & -25 \\ & & & \\ \odot & 5,544 & 2,250 & 681 \\ \odot & 2,681 & 2,250 & 508 \\ \odot & -2,862 & 0 & -173 \\ \odot & -52 & \odot & -25 \\ & & & \\ \odot & 185 & 75 & 23 \\ \odot & 89 & 75 & 17 \\ \odot & -95 & \odot & -6 \\ \odot & -52 & \odot & -25\end{array}$

Motors and Misc Equip

$\begin{array}{rrrr} & \text { Cooling } & \text { Vent } & \text { Lights } \\ \odot & 1,624,274 & 659,145 & 199,426 \\ \odot & 785,607 & 659,145 & 148,759 \\ \odot & -838,667 & 0 & -50,667 \\ \odot & -52 & 0 & -25 \\ & & & \\ \odot & 5,544 & 2,250 & 681 \\ \odot & 2,681 & 2,250 & 508 \\ \odot & -2,862 & 0 & -173 \\ \odot & -52 & 0 & -25 \\ & & & \\ \odot & 185 & 75 & 23 \\ \odot & 89 & 75 & 17 \\ \odot & -95 & 0 & -6 \\ \odot & -52 & 0 & -25\end{array}$

Total (MMBtu/1000ft2)

existing

post-retrofit

difference

$\%$ change

$\odot$

$2,960,248$
$2,960,248$
0
0

10,103
10,103
$\odot$
0

337
337
0
$\odot$

Hot Water *

* Energy consumption values for both distributed and central SHW are reported for Hot Water annual energy use. 


\section{Emission Reduction}

The emission reductions from implementing the proposed retrofits are as follows:

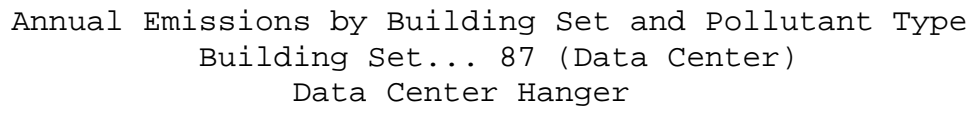

41,169

$-8,059$

$-16$

Nitrogen 0xides (lb)

existing

post-retrofit

23,524

difference

19,673

$\%$ change

$-3,851$

$-16$

Carbon Monoxide (lb)

existing

post-retrofit

40,461

difference

$\%$ change

33,837

$-6,624$

$-16$

Carbon Dioxide (tons)

existing

post-retrofit

difference

$\%$ change

4,983

4,167

$-816$

$-16$

Particulate Matter (lb)

existing

post-retrofit

difference

$\%$ change

974

814

$-159$

$-16$

Hydrocarbons (1b)

existing

post-retrofit

16,746

difference

$\%$ change

14,004

$-2,741$

\section{Additional Considerations}

This assessment was limited to developing the model and producing the typical retrofits that are built into the FEDS model. As part of the current PACOM ARRA funding, Lawrence Berkeley National Laboratory will be studying other efficiency measures in the data center.

\section{Photos}

Because of security concerns, building photos were not permitted during the audit.

Publicly available satellite images show the exterior of Building 87. 


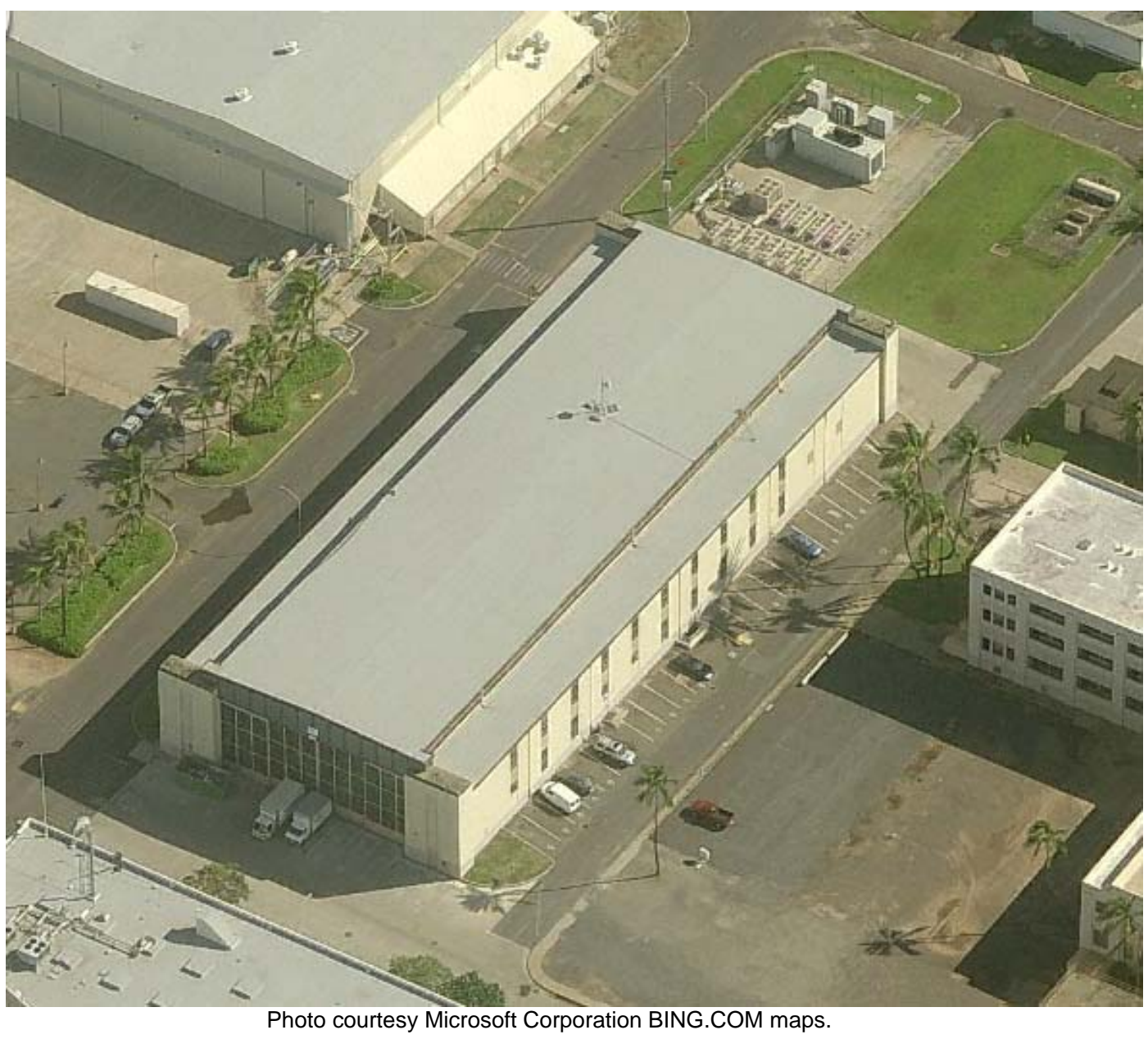

Figure C1. Building 87 Satellite Image 


\section{Building 167 Engineering Warehouse}

Building 167 is a 450,000 $\mathrm{ft}^{2}$ mixed-use building. Large areas of unconditioned storage space occupy the lower three floors. Unconditioned warehouse space accounts for $193,500 \mathrm{ft}^{2}$ of space and $43 \%$ of the building total. Administrative spaces occupy the top two floors and parts of floors 1 through 3 . Administrative space accounts for $256,500 \mathrm{ft}^{2}$ of space and 57\% of the total building. The upper floors also have small laboratory, electronics and testing spaces. The first floor also houses a control/situation room and computer lab.

The building is primarily cooled by the chilled water plant located directly across the street from 167. This plant has three 800-ton water-cooled chillers installed in 1999. In addition to the central chiller plant, supplemental cooling is provided by multiple aircooled chillers and package units.

Building 167 has mix of lighting vintages and types because the building use has changed and equipment has been replaced on an ad hoc basis. The storage areas of the building have predominantly older T12 lighting. Approximately 75\% of the lighting is 8-foot, 2tube T12 fluorescent, while the remainder is 8-foot, 2-tube T8 fluorescent. The administrative space and small labs are predominantly T8 fluorescent in the form of 8foot 2-tube T8 (20\%), 2x4 2-tube T8 (2\%), 2x4 3-tube T8 (19\%), 2x4 4-tube T8 (2\%), 4foot 2-tube T8 (35\%), and 2x2 2-tube U-shaped T8 (2\%).

The building has a range of use types including unconditioned storage, standard office, small labs, and a small control center. The control room has a small computer center with dedicated air-conditioning system and UPS. 


\section{Energy Consumption by Fuel Type}

The actual metered energy consumption for FY2009 was 5,530,000 kWh. The modeled electrical consumption for a typical year (not including central plant energy) was 4,341,739 kWh before retrofits and 3,883,019 kWh after proposed retrofits are implemented. The energy use intensity goes from 72.9 MMBtu/Ksf to 65.7 MMBtu/Ksf after retrofits.

Annual Energy Use by Building Set and Fuel Type

Building Set ... 167

Warehouse (Admin)

Fuel

Energy

Intensity

(user units/1000ft2)

Intensity

Dollars

(MMBtu/1000ft2) (2009)*

Electricity (kWh)

existing

4, 341, 739

post-retrofit

difference

$3,883,019$

$-458,720$

9,648

8,629

$(1,019)$

32.9

29.4

(3.5)

741,517

10.6

10.6

Central chilled water

existing

$1,498,293$

$1,360,479$

3,330

3,023

post-retrofit

$-137,814$

(306)

$\%$ change

9.2

9.2

40.0

36.3

-3.7
9.2

659,341

$(82,176)$

11.1

Total (MMBtu)

existing

32,798

29,579

$-3,219$

72.9

65.7

(7.2)

72.9

65.7

(7.2)

$\%$ change

9.8

9.8

9.8

173,444

157,490

$(15,954)$

9.2

914,961

816,831

$(98,130)$ 


\section{Energy Consumption by End Uses}

Cooling is the largest energy consumer in the facility with 19,908 MMBtu/year, while motors and other miscellaneous loads are estimated to consume 5,993 MMBtu/year.

$$
\begin{aligned}
& \text { Annual Energy Use by Building Set, Fuel Type, and End Use } \\
& \text { Building Set ... } 167
\end{aligned}
$$

Fuel

$$
\text { Heating }
$$

Cooling

Vent

Lights

Motors and

Electricity $(\mathrm{kWh})$

existing

post-retrofit

difference

$\odot$

$\odot$

$\%$ change

564,661
511,737
$(52,924)$
9.4

574,082

517,053

$\odot . \odot$

9.4

$(57,029)$

9.9

Misc Equip

Hot Water *

Central chilled water

existing

$1,498,293$

$1,360,479$

ost-retrofit

0
0

difference

$(137,814)$

$\%$ change

9.2

Total (MMBtu)

existing

post-retrofit

difference

$\odot$
$\odot$
$\odot$
$\odot . \odot$

19,908
18,073
$(1,835)$
9.2

\section{1,959}

1,765

$\%$ change

(194)

Total (MMBtu/1000ft2)

existing

$\odot$

post-retrofit

difference

$\odot . \odot$

$\%$ change

$\begin{array}{cc}78 & 8 \\ 70 & 7 \\ (8) & (1) \\ 10.3 & 12.5\end{array}$

* Energy consumption values for

both distributed

$1,095,565$
$(333,501)$

23.3
$1,755,819$
$1,755,819$
18,111
2,845
$(15,266)$
$\odot . \odot$
84.3

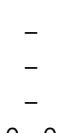

$\odot . \odot$

$\odot . \odot$

$\odot . \odot$

4,877
3,739
$(1,138)$
23.3

5,993

5, 993

○. 0

62

10

$(52)$
83.9

83.9

$\begin{array}{ccc}20 & 25 & - \\ 15 & 25 & - \\ (5) & - & - \\ 25.0 & 0.0 & 0.0\end{array}$

and central SH $W$ are reported $f$ or

Hot Water annual energy use. 


\section{Emission Reduction}

The emission reductions from implemented the proposed retrofits are as follows:

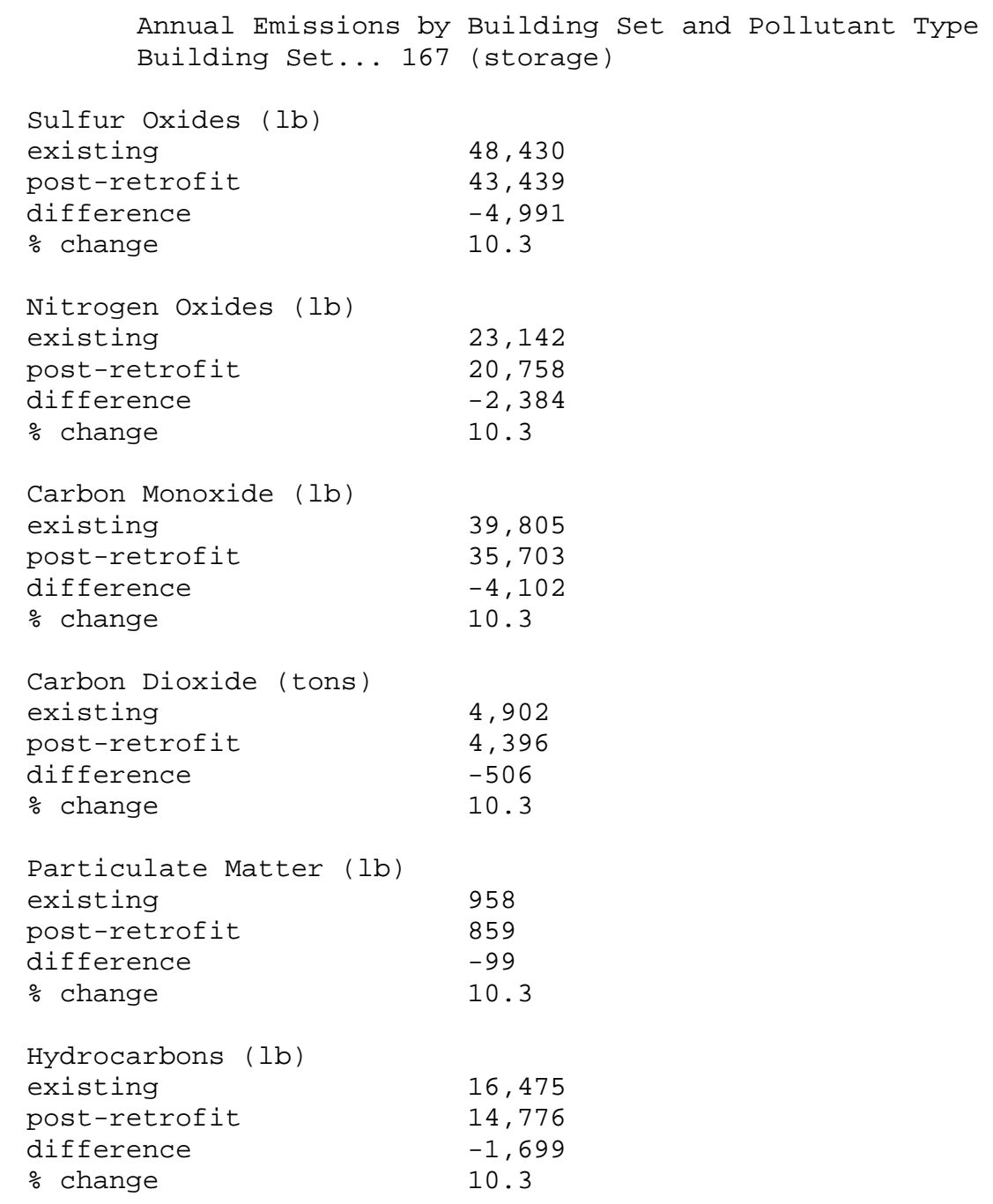

\section{Additional Considerations}

The storage areas should be evaluated for zone-based occupancy sensors to control existing lighting. Specific implementation of controls and zoning are not automatically included in the FEDS energy model.

\section{Photos}

Because of security concerns, building photos were not permitted during the audit. Publicly available satellite images show the exterior of Building 167. 


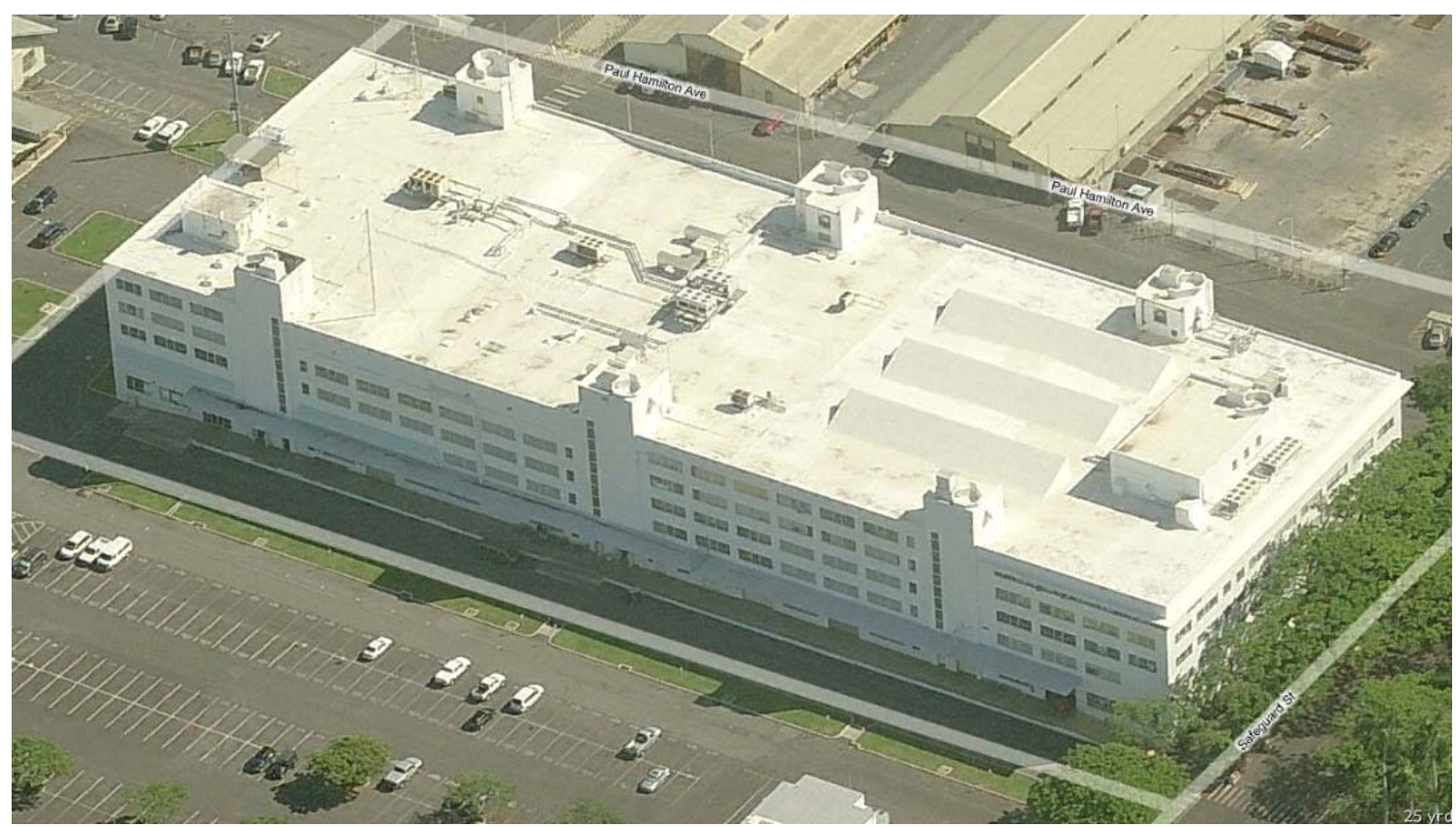

Photo courtesy Microsoft Corporation BING.COM maps.

Figure C2. Building 167 Satellite Imagery 


\section{Building 440}

Building 440 (including 440A) is a 68,000 $\mathrm{ft}^{2}$ mixed-use building with administrative space and both conditioned and unconditioned shops. The building is comprised of three sections built in different eras. The original structure sits roughly in the middle and consists of a mixture of shop and office space. An east wing was added later that contains a supply area and lunchroom. The most recent addition (440A) also consists of a mixture of shops and offices. This portion of the building has several high-bay rooms. About $20 \%$ of $440 \mathrm{~A}$ and $10 \%$ of the original structure are not cooled. The east wing is entirely cooled.

Space cooling is provided by a combination of air-cooled chillers and direct expansion (DX) equipment. Two 60-ton Trane chillers serve the 440A addition. Three 5.83 ton Filtrine chillers provide direct cooling of test equipment in 440A. Two more 5.83-ton Filtrine chillers cool equipment in the original structure. The shop that is served by the two Filtrine chillers is also served by a 40-ton DX unit (no access to roof, so manufacturer is unknown). The northern half of the original building and the east wing are served by three 20-ton Trane DX units and several single-room DX units. Finally, the south end of the main building is served by a 40-ton Trane chiller.

Building lighting consists of a wide array of fixture types, sizes, and number of lamps per fixture, but it appears to be entirely T-8 fluorescent. There are about two dozen incandescent can lamps in the conference room, but that technology is required to allow dimming when needed. Exit signs are LED type. 


\section{Energy Consumption by Fuel Type}

The actual metered energy consumption for FY2009 was 1,335,680 kWh. The modeled energy consumption for a typical year was 1,247,303 kWh before retrofits and 946,089 kWh after proposed retrofits are implemented. The energy use intensity goes from 62.4 $\mathrm{MMBtu} / \mathrm{ksf}$ to $47.3 \mathrm{MMBtu} / \mathrm{ksf}$ after retrofits.

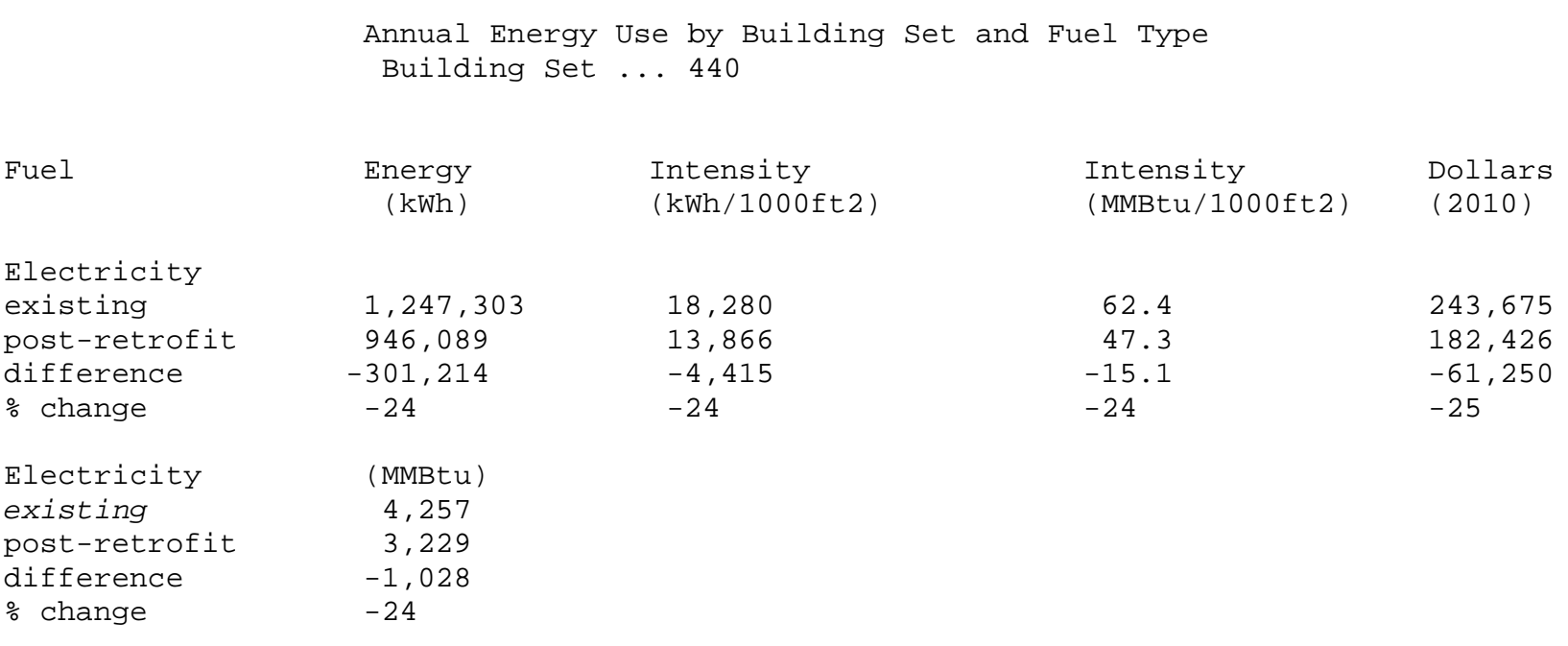




\section{Energy Consumption by End Uses}

Cooling is estimated to consume 1,601 MMBtu/year, while motors and equipment are the second largest use at 1,260 MMBtu/year. Ventilation and lighting energy use are approximately the same and combine to consume 1,375 MMBtu/year.

Annual Energy Use by Building Set, Fuel Type, and End Use Building Set ... 440

Fuel

Heating

Cooling

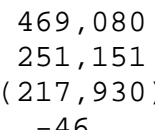

Vent

ectricity (kWh)

existing

post-retrofit

difference

$\%$ change

Lights

Motors and Misc Equip

Hot Water

\section{Electricity (MMBtu)}

existing

post-retrofit

difference

$\%$ change

179,584
127,036

$(52,548)$

369,171

369,171

6,328

$-29$

1,601
857

857
$(744)$

762
657
$(105)$
-14

23.5
12.6
$(10.9)$
-46

11.2
9.6
$(1.6)$
-14

9.0

6.4

$(2.6)$
-29

1,260

18.5

18.5

0.3

$\odot$

46

$\%$ change 


\section{Emission Reduction}

Current and prospective indirect (at the utility power plant) emissions from implementing the proposed retrofits are as follows:

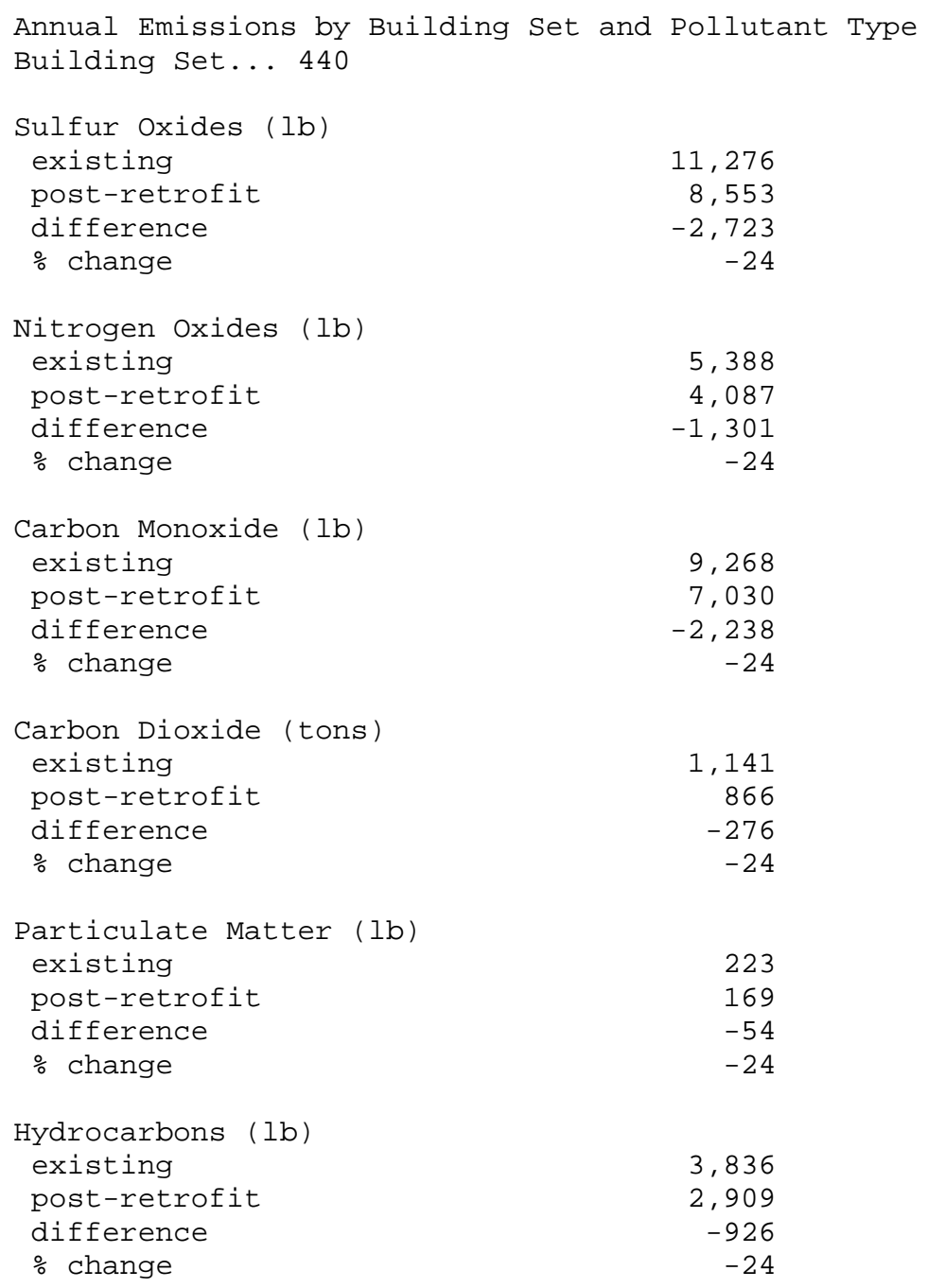

\section{Additional Considerations}

Combining and replacing the existing three air-cooled chillers (not counting the Filtrine equipment coolers) with a pair of water-cooled chillers would save energy, but should be evaluated for cost-effectiveness.

\section{Photos}

Because of security concerns, building photos were not permitted during the audit. Publicly available satellite images show the exterior of Building 440 . 


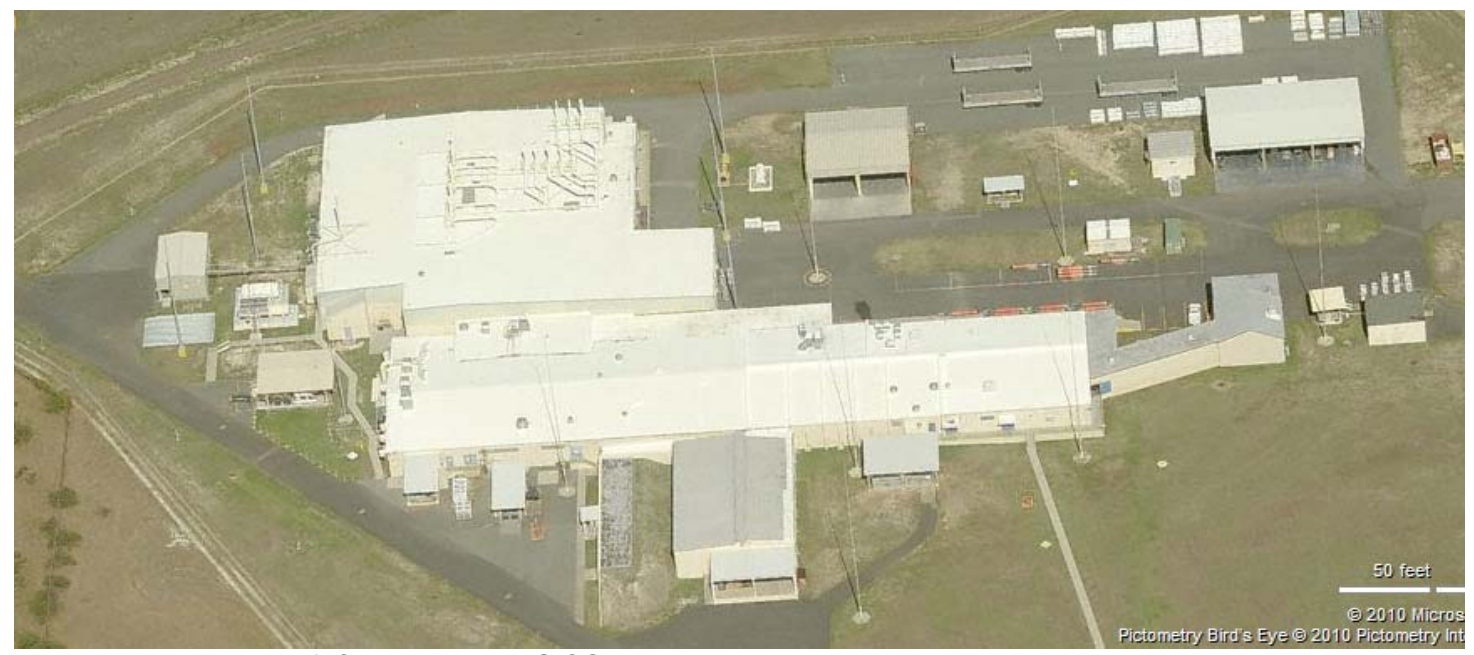

Photo courtesy Microsoft Corporation BING.COM Maps.

Figure C3. Building 440 Satellite Imagery 


\section{Building 475}

Building 475 is a $288,000 \mathrm{ft}^{2}$ mixed-use building with administrative space, unconditioned warehouse space, and a data center. Unconditioned storage is the predominant use type in the building representing 190,400 $\mathrm{ft}^{2}$ and roughly $66 \%$ of the floor area. Unconditioned storage is found on floors 4, 5, and 6; the south receiving dock on the first floor; and a small, unused area on the $3^{\text {rd }}$ floor. Approximately, 82,400 $\mathrm{ft}^{2}$ ( $29 \%$ of the total area) is dedicated to administrative space, including all of the $2^{\text {nd }}$ floor and parts of floors 1 and 3 . Finally, a $15,200 \mathrm{ft}^{2}$ data center is located on the $3^{\text {rd }}$ floor.

Space cooling is provided by ten air-cooled chillers with a 200-ton total capacity located on the roof. Only the administrative spaces and the data center are currently cooled by air-handling units in the zone.

Lighting in the administrative spaces is provided by 2x4 2-tube T8 where suspended ceiling exists or 4-foot 2-tube T8 direct/indirect lighting over cubicals in open spaces. Storage areas have 4-foot 2-tube T8 surface mounted lighting. The receiving dock on the first floor has a few metal halide lights. 


\section{Energy Consumption by Fuel Type}

The actual metered energy consumption for FY2009 was 5,984,000 kWh. The modeled energy consumption for a typical year was 6,015,439 kWh before retrofits and 4,953,940 kWh after proposed retrofits are implemented. The energy use intensity goes from 71.3 $\mathrm{MMBtu} / \mathrm{Ksf}$ to $58.7 \mathrm{MMBtu} / \mathrm{Ksf}$ after retrofits.

\begin{tabular}{|c|c|c|c|c|}
\hline & $\begin{array}{l}\text { Annual Ener } \\
\text { Building } \$\end{array}$ & $\begin{array}{l}\text { se by Building set an } \\
\ldots 475\end{array}$ & uel Type & \\
\hline Fuel & Energy & $\begin{array}{l}\text { Intensity } \\
\text { (user units/1000ft2) }\end{array}$ & $\begin{array}{l}\text { Intensity } \\
\text { (MMBtu/100०ft2) }\end{array}$ & $\begin{array}{l}\text { Dollars } \\
(20 \odot 9)^{*}\end{array}$ \\
\hline Electricity & & & & \\
\hline existing & $6,015,439$ & 20,887 & 71.3 & $1,027,365$ \\
\hline $\begin{array}{l}\text { post-retrofit } \\
\text { difference }\end{array}$ & $\begin{array}{l}4,953,940 \\
-1,061,499\end{array}$ & $\begin{array}{l}17,201 \\
(3,686)\end{array}$ & $\begin{array}{l}58.7 \\
(12.6)\end{array}$ & $\begin{array}{l}841,185 \\
\quad(186,180)\end{array}$ \\
\hline$\%$ change & 17.6 & 17.6 & 17.6 & 18.1 \\
\hline Total (MMBtu) & & & & \\
\hline existing & 20,525 & 71.3 & 71.3 & $1,027,365$ \\
\hline post-retrofit & 16,903 & 58.7 & 58.7 & 841,185 \\
\hline difference & $-3,622$ & $(12.6)$ & $(12.6)$ & $(186,180)$ \\
\hline$\%$ change & 17.6 & 17.6 & 17.6 & 18.1 \\
\hline
\end{tabular}




\section{Energy Consumption by End Uses}

The motors and other miscellaneous loads are the largest consumers, using an estimated 7,385 MMBtu/year. Cooling is the second largest consumer with over 6,449 MMBtu/year. Lighting energy use was quite high in the facility with over 4,140 MMBtu/year, primarily the result of shift work and HID lighting.

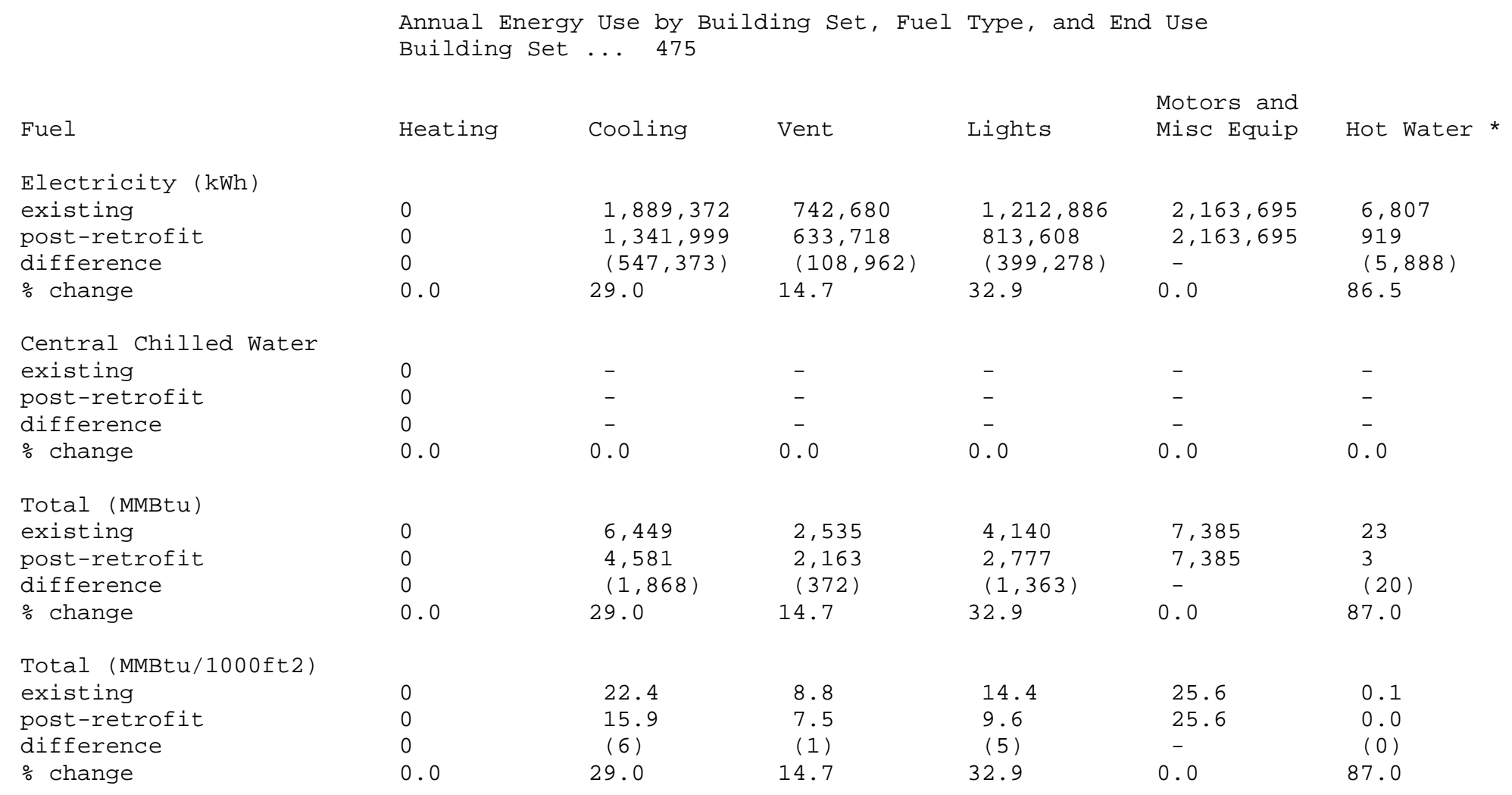

* Energy consumption values for both distributed and central SHW are reported for Hot Water annual energy use. 


\section{Emission Reduction}

The emission reductions from implementing the proposed retrofits are as follows:

\begin{tabular}{|c|c|}
\hline Sulfur Oxides (lb) & \\
\hline existing & 54,380 \\
\hline post-retrofit & 44,784 \\
\hline difference & $-9,596$ \\
\hline$\%$ change & 17.6 \\
\hline Nitrogen Oxides (lb) & \\
\hline existing & 25,986 \\
\hline post-retrofit & 21,400 \\
\hline difference & $-4,586$ \\
\hline$\%$ change & 17.6 \\
\hline Carbon Monoxide (lb) & \\
\hline existing & 44,696 \\
\hline post-retrofit & 36,808 \\
\hline difference & $-7,888$ \\
\hline$\%$ change & 17.6 \\
\hline Carbon Dioxide (tons) & \\
\hline existing & 5,505 \\
\hline post-retrofit & 4,533 \\
\hline difference & -972 \\
\hline$\%$ change & 17.7 \\
\hline Particulate Matter (lb) & \\
\hline existing & 1,076 \\
\hline post-retrofit & 886 \\
\hline difference & -190 \\
\hline$\%$ change & 17.7 \\
\hline Hydrocarbons (lb) & \\
\hline existing & 18,499 \\
\hline post-retrofit & 15,234 \\
\hline difference & $-3,265$ \\
\hline$\%$ change & 17.6 \\
\hline
\end{tabular}

\section{Additional Considerations}

The storage areas should be evaluated for zone-based occupancy sensors to control existing lighting. Specific implementation of controls and zoning are not automatically included in the FEDS energy model.

\section{Photos}

Because of security concerns, building photos were not permitted during the audit. Publicly available satellite images show the exterior of Building 475. 


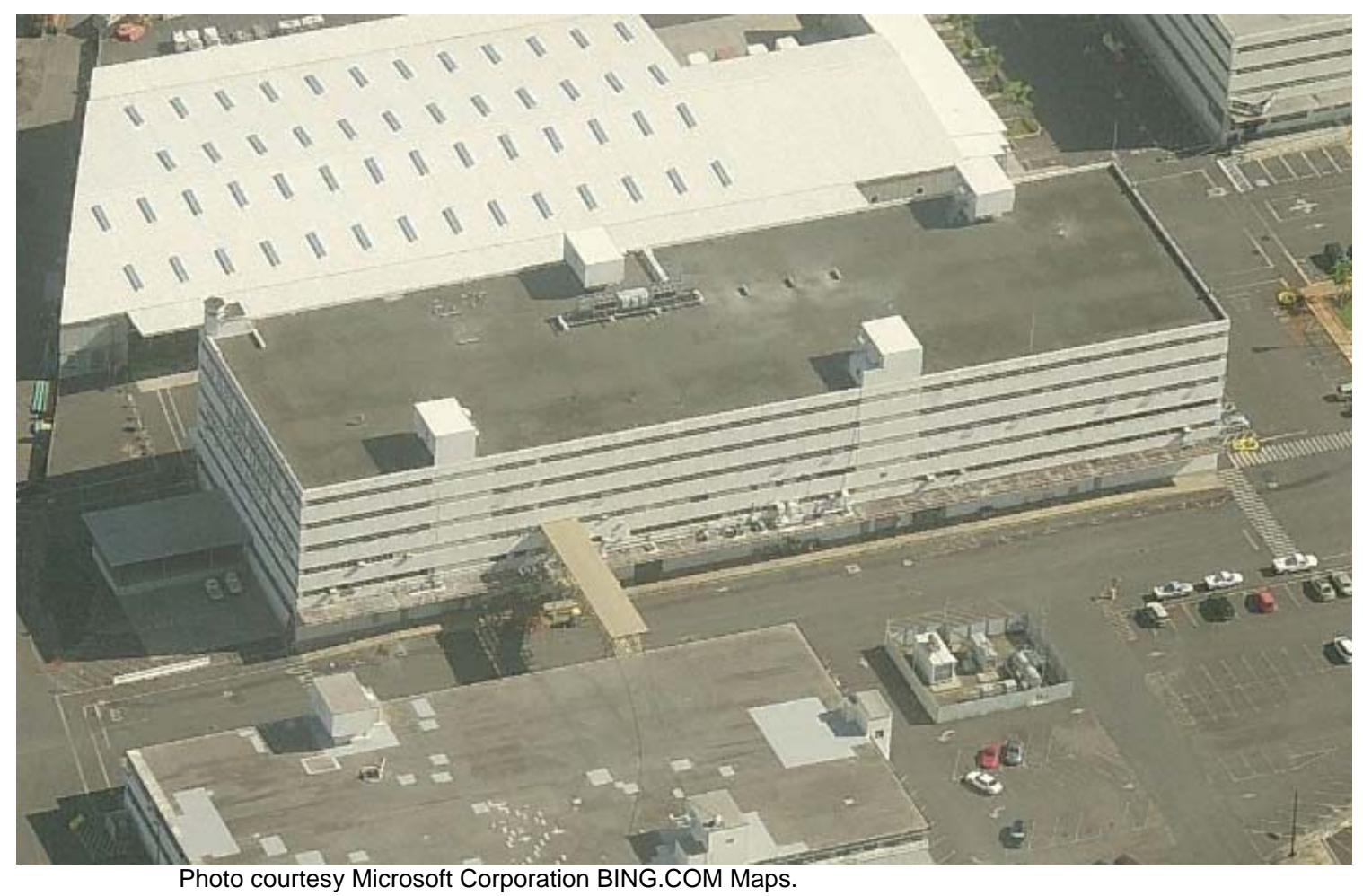

Figure C4. Building 475 Satellite Imagery 


\section{Building 631 Naval Exchange (NEX)}

Building 631, the Naval Exchange building, was built in 2002 and covers 285,515 $\mathrm{ft}^{2}$. It is the largest Exchange in the military. It is actually more similar to a small shopping mall than just a retail store. It is attached to the Commissary by a common wall (not covered in this assessment), and includes a large, 2-story atrium and attached food court.

Cooling is provided by 24 roof-top units with a total cooling capacity of 659 tons.

Lighting in the store is provided predominantly by $2 \times 42$-tube $\mathrm{T} 8$ fixures. Additional display or specialty lighting is present in many areas such as 2-lamp CFL recessed fixtures, R20 INC track lighting, and biaxial fluorescent wall washing fixtures.

Service hot water is provided by electric hot water heaters in the store restrooms and propane water heaters in the food service area. 


\section{Energy Consumption by Fuel Type}

The actual metered energy consumption (Exchange only) for FY2009 was 5,331,120 kWh, making it one of the largest energy consumers on base. The modeled energy consumption for a typical year was 5,843,265 kWh before retrofits and 4,304,693 kWh after proposed retrofits are implemented. The energy use intensity goes from 69.8 MMBtu/Ksf to 51.4 MMBtu/Ksf after retrofits.

Annual Energy Use by Building set and Fuel Type

Building set ...6631

\begin{tabular}{|c|c|c|c|c|}
\hline Fuel & Energy & $\begin{array}{l}\text { Intensity } \\
\text { (user units/1000ft2) }\end{array}$ & $\begin{array}{l}\text { Intensity } \\
\text { (MMBtu/1000ft2) }\end{array}$ & $\begin{array}{l}\text { Dollars } \\
(2009)^{*}\end{array}$ \\
\hline \multicolumn{5}{|c|}{ Electricity (kWh) } \\
\hline existing & $5,843,265$ & 20,466 & 69.8 & 997,960 \\
\hline $\begin{array}{l}\text { post-retrofit } \\
\text { difference }\end{array}$ & $\begin{array}{l}4,304,693 \\
-1,538,572\end{array}$ & $\begin{array}{l}15,077 \\
(5,389)\end{array}$ & $\begin{array}{l}51.4 \\
(18.4)\end{array}$ & $\begin{array}{l}730,942 \\
(267,018)\end{array}$ \\
\hline$\%$ change & 26.3 & 26.3 & 26.3 & 26.8 \\
\hline \multicolumn{5}{|c|}{ Other Fuels (MMBtu) } \\
\hline existing & 75 & 0.3 & 0.3 & 1,684 \\
\hline post-retrofit & $\odot$ & - & $\odot . \odot$ & $\odot$ \\
\hline difference & -75 & $(0.3)$ & -0.3 & $(1,684)$ \\
\hline$\%$ change & 100 & 100 & 100 & 100 \\
\hline \multicolumn{5}{|l|}{ Total (MMBtu) } \\
\hline existing & 19,937 & 69.8 & 69.8 & 245,508 \\
\hline post-retrofit & 14,688 & 51.4 & 51.4 & 224,434 \\
\hline difference & $-5,250$ & $(18.4)$ & $(18.4)$ & $(21,074)$ \\
\hline$\%$ change & 26.3 & 26.3 & 26.3 & 8.6 \\
\hline
\end{tabular}




\section{Energy Consumption by End Uses}

Because the NEX is primarily retail and has long hours, lighting is the largest end-use with 2,098,352 MMBtu/year, while cooling is the second largest consumer, using over 1,889,549 kWh/year.

\section{Annual Energy Use by Building Set, Fuel Type, and End Use} Building Set ... 631

Fuel

\section{Heating}

Cooling Vent

Lights

Motors and

Electricity (kWh)

existing

post-retrofit

difference

$\%$ change

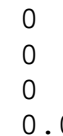

$1,889,549$

$1,069,912$
530,504
506,058
$(24,446)$

$(819,637)$

$\odot . \odot$

43.4

4.6

$2,098,352$

$1,482,366$

Misc Equip

Hot Water *

Other Fuels (MMBtu)

existing

post-retrofit

difference

$\begin{array}{ll}\odot & - \\ \odot & - \\ \odot & \odot \\ \odot . \odot & \odot . \odot\end{array}$

$\begin{array}{ll}- & - \\ - & - \\ 0 & 0 \\ 0.0 & 0.0\end{array}$

$(615,986)$

29.4

$\begin{array}{ll}1,232,050 & 92,812 \\ 1,232,050 & 14,309 \\ - & (78,503) \\ \odot . \odot & 84.6\end{array}$

$\%$ change

$\begin{array}{ll}0 & - \\ 0 & 0\end{array}$

existing

post-retrofit

difference

$\%$ change

0.0

$\odot$

-
-
0

$0^{-}$

75

$-75$

100.0

Total (MMBtu)

existing

post-retrofit

difference

$\%$ change

$\begin{array}{lll}\odot & 4,793 & 1,315 \\ \odot & 2,147 & 1,237 \\ \odot & -2,646 & -78 \\ \odot . \odot & 55.2 & 5.9\end{array}$

Total (MMBtu/1000ft2)

existing

post-retrofit

difference

$\%$ change

$\begin{array}{lllccc}\odot & 16.8 & 4.6 & 22.3 & 8.0 & 1.1 \\ 0 & 7.5 & 4.3 & 15.7 & 8.0 & 0.1 \\ \odot & -9 & 0 & -7 & 0 & -1 \\ 0.0 & 55.2 & 5.9 & 29.7 & 0.0 & 87.1\end{array}$

* Energy consumption values for both distributed and central SHW are reported for Hot Water annual energy use. 


\section{Emission Reduction}

The emission reductions from implementing the proposed retrofits are as follows:

\begin{tabular}{|c|c|}
\hline \multicolumn{2}{|l|}{ Sulfur Oxides (lb) } \\
\hline existing & 52,842 \\
\hline $\begin{array}{l}\text { post-retrofit } \\
\text { difference }\end{array}$ & $\begin{array}{l}38,915 \\
-13,927\end{array}$ \\
\hline$\%$ change & 26.4 \\
\hline \multicolumn{2}{|l|}{ Nitrogen Oxides (lb) } \\
\hline existing & 25,268 \\
\hline post-retrofit & 18,596 \\
\hline difference & $-6,672$ \\
\hline$\%$ change & 26.4 \\
\hline \multicolumn{2}{|l|}{ Carbon Monoxide (lb) } \\
\hline existing & 43,473 \\
\hline post-retrofit & 31,985 \\
\hline difference & $-11,488$ \\
\hline$\%$ change & 26.4 \\
\hline \multicolumn{2}{|l|}{ Carbon Dioxide (tons) } \\
\hline existing & 5,353 \\
\hline post-retrofit & 3,938 \\
\hline difference & $-1,415$ \\
\hline$\%$ change & 26.4 \\
\hline \multicolumn{2}{|l|}{ Particulate Matter (lb) } \\
\hline existing & 1,046 \\
\hline post-retrofit & 769 \\
\hline difference & -277 \\
\hline$\%$ change & 26.5 \\
\hline \multicolumn{2}{|l|}{ Hydrocarbons (lb) } \\
\hline existing & 4,409 \\
\hline $\begin{array}{l}\text { post-retrofit } \\
\text { difference }\end{array}$ & $\begin{array}{l}4,065 \\
-344\end{array}$ \\
\hline$\%$ change & 7.8 \\
\hline
\end{tabular}

\section{Additional Considerations}

None.

\section{Photos}

The following photo's show current building condition. 


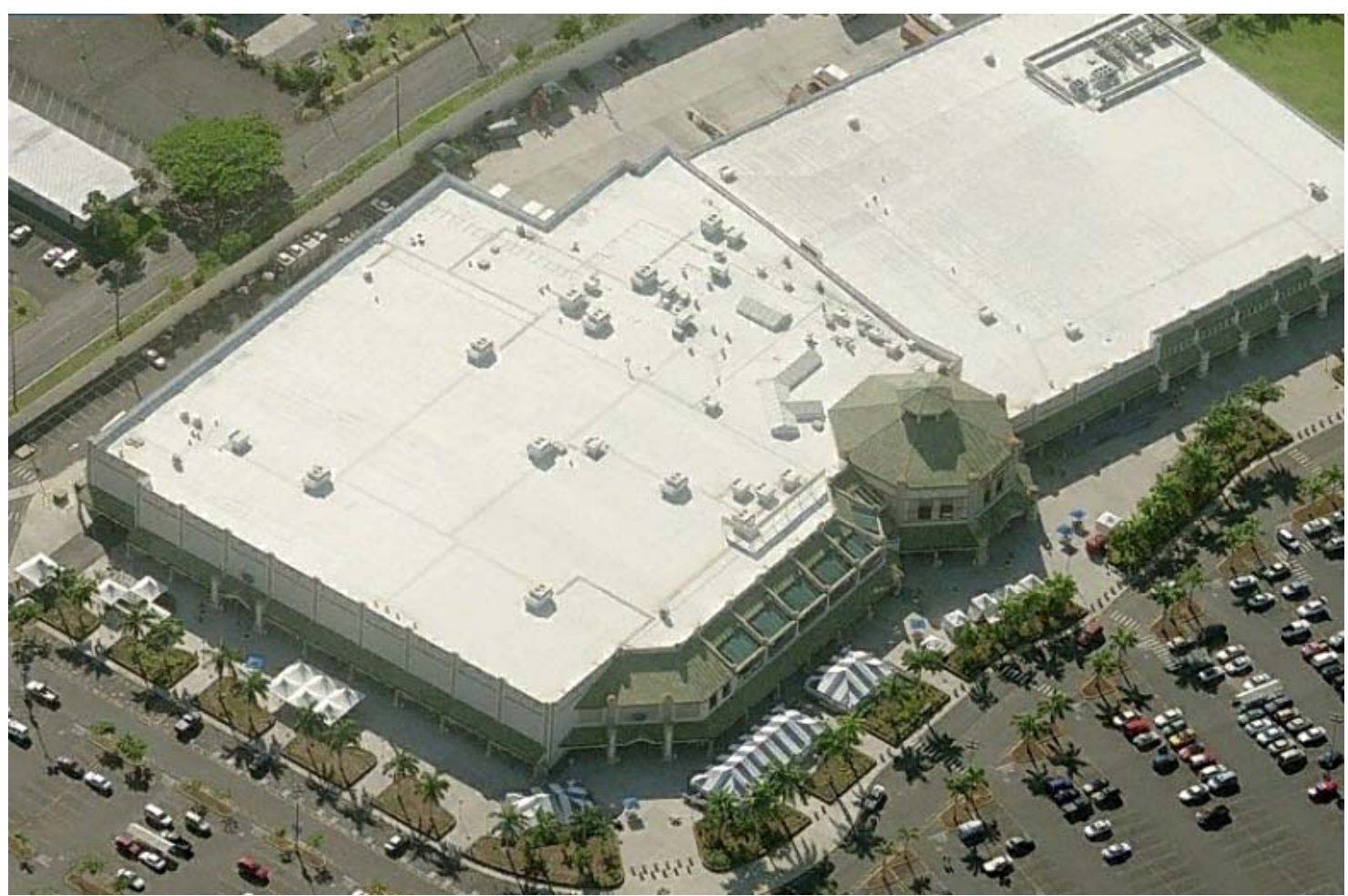

Photo courtesy Microsoft Corporation BING.COM

Figure C5. Building 631 Satellite Imagery

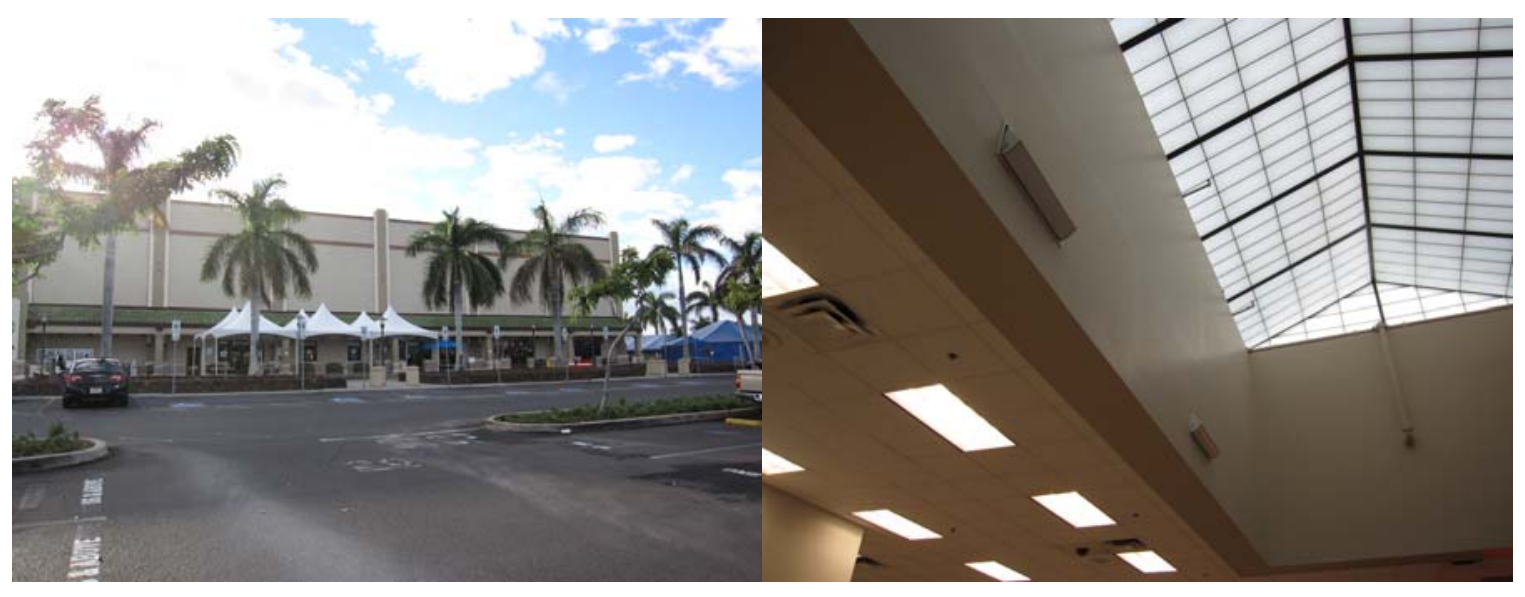

Figure C6. Miscellaneous Photos of NEX 


\section{Building 1670}

Building 1670 is a 141,354 $\mathrm{ft}^{2}$ mixed use building consisting of administrative space, high bay space, shops, and a large sewing area. Small administrative areas are dispersed throughout the building, although the west one story addition is dedicated to administrative functions. The large high bay is unconditioned, although small portable/trailers are used as office space, cooled by window units. A number of other shops are housed in the building including rigging shops, small machine shops, and a sand blasting shop. Because of the activity in the building and nearby work, a large shower facility is located on the second floor of the two story section. Finally, the east end of the building is a two-story addition that houses the sewing functions on the top floor.

Cooling on the one-story administrative addition is provided by a roof-mounted aircooled package unit. The high bay spaces are uncooled, except for office areas, which are cooled by window units as noted. The two-story section has two roof-mounted aircooled chillers.

The one-story administrative addition is lit entirely with 2x4 2-tube and 2x2 U-tube F32T8 lights in the suspended ceiling. The high bay shop area has 60 skylights and the sewing shop has 20 skylights, which provide light to the space. The skylights are of poor quality with no dispersion of light, which creates strong light areas and shadows on the work space below. When people move around the space below, their eyes have to constantly adjust to the shadows and beams of light. Approximately 72, 400-watt metal halide pendent lights provide light to the high bay, although there was ample natural light at the time of the visit. The 2-story section has 36, 250-watt metal halide pendent lights in the sewing space. Miscellaneous T8 fluorescent lighting is scattered throughout.

Hot water for the shower area is provided by an electric water heater with two, 300 gallon tanks. With over 32 shower heads, the model estimates that over 400 gallons of hot water is used each day. 


\section{Energy Consumption by Fuel Type}

The actual metered energy consumption for FY2009 was 1,870,080 kWh. The modeled energy consumption for a typical year was $1,927,940 \mathrm{kWh}$ before retrofits and 1,566,848 $\mathrm{kWh}$ after proposed retrofits are implemented. The energy use intensity goes from 46.5 $\mathrm{MMBtu} / \mathrm{Ksf}$ to $37.8 \mathrm{MMBtu} / \mathrm{Ksf}$ after retrofits.

Annual Energy Use by Building Set and Fuel Type Building set ... 1670

Fuel

Electricity (kWh)

existing

post-retrofit

difference

$\%$ change

Total (MMBtu)

existing

post-retrofit

difference

$\%$ change
Energy

Intensity
(user units/

(user units/1000ft2)

$1,927,940$

$1,566,848$

$-361,092$

18.7

$$
\begin{aligned}
& 13,639 \\
& 11,085 \\
& (2,555)
\end{aligned}
$$

18.7

$\begin{array}{lr}6,580 & 47 \\ 5,348 & 38 \\ -1,232 & (9) \\ 18.7 & 18.7\end{array}$

Intensity Dollars

(MMBtu/1000ft2) (2009)*

$\begin{array}{lc}46.5 & 329,268 \\ 37.8 & 266,052 \\ (8.7) & (63,216) \\ 18.7 & 19.2 \\ & \\ 46.5 & 329,268 \\ 37.8 & 266,052 \\ (8.7) & (63,216) \\ 18.7 & 19.2\end{array}$




\section{Energy Consumption by End Uses}

The motors and other miscellaneous loads are estimated to consume 693,189 kWh/year, while cooling is the second largest consumer with over 580,164 kWh/year. Lighting energy use was quite high in the facility with over 500,506 kWh/year, primarily the result of shift work and HID lighting.

Annual Energy Use by Building Set, Fuel Type, and End Use Building Set ... 1670

\begin{tabular}{|c|c|c|c|c|c|c|}
\hline Fuel & Heating & Cooling & Vent & Lights & $\begin{array}{l}\text { Motors and } \\
\text { Misc Equip }\end{array}$ & Hot Water \\
\hline \multicolumn{7}{|c|}{ Electricity (kWh) } \\
\hline existing & - & 567,052 & 145,162 & 500,506 & 693,189 & 22,032 \\
\hline post-retrofit & - & 351,225 & 136,175 & 372,010 & 693,189 & 14,252 \\
\hline difference & $\odot$ & $(215,827)$ & $(8,987)$ & $(128,496)$ & - & $(7,780)$ \\
\hline$\%$ change & $\odot . \odot$ & 38.1 & 6.2 & 25.7 & 0.0 & 35.3 \\
\hline \multicolumn{7}{|l|}{ Total (MMBtu) } \\
\hline existing & - & 1,935 & 495 & 1,708 & 2,365 & 76 \\
\hline post-retrofit & - & 1,198 & 465 & 1,270 & 2,365 & 49 \\
\hline difference & $\odot$ & -737 & -30 & -438 & 0 & -27 \\
\hline$\%$ change & $\odot .0$ & 38.1 & 6.1 & 25.6 & $\odot . \odot$ & 35.5 \\
\hline \multicolumn{7}{|c|}{ Total (MMBtu/1000ft2) } \\
\hline existing & $\odot$ & 13.7 & 3.5 & 12.1 & 16.7 & 0.5 \\
\hline post-retrofit & $\odot$ & 8.5 & 3.3 & 9.0 & 16.7 & 0.3 \\
\hline difference & $\odot$ & -5 & $\odot$ & -3 & 0 & $\odot$ \\
\hline$\%$ change & $\odot . \odot$ & 38.1 & 6.1 & 25.6 & $\odot . \odot$ & 35.5 \\
\hline
\end{tabular}

* Energy consumption values for both distributed and central SHW are reported for Hot water annual energy use. 


\section{Emission Reduction}

The emission reductions from implementing the proposed retrofits are as follows:

\begin{tabular}{|c|c|}
\hline Sulfur 0xides (lb) & \\
\hline existing & 17,429 \\
\hline post-retrofit & 14,164 \\
\hline difference & $-3,265$ \\
\hline \% change & 18.7 \\
\hline Nitrogen Oxides (lb) & \\
\hline existing & 8,328 \\
\hline post-retrofit & 6,768 \\
\hline difference & $-1,560$ \\
\hline$\%$ change & 18.7 \\
\hline Carbon Monoxide (lb) & \\
\hline existing & 14,325 \\
\hline post-retrofit & 11,642 \\
\hline difference & $-2,683$ \\
\hline$\%$ change & 18.7 \\
\hline Carbon Dioxide (tons) & \\
\hline existing & 1,764 \\
\hline post-retrofit & 1,434 \\
\hline difference & -330 \\
\hline$\%$ change & 18.7 \\
\hline Particulate Matter (lb) & \\
\hline existing & 344 \\
\hline post-retrofit & 281 \\
\hline difference & -63 \\
\hline$\%$ change & 18.3 \\
\hline Hydrocarbons (lb) & \\
\hline existing & 5,929 \\
\hline post-retrofit & 4,818 \\
\hline difference & $-1,111$ \\
\hline \% change & 18.7 \\
\hline
\end{tabular}

\section{Additional Considerations}

None.

\section{Photos}

Because of security concerns, building photos were not permitted during the audit. Publicly available satellite images show the exterior of Building 1670. 


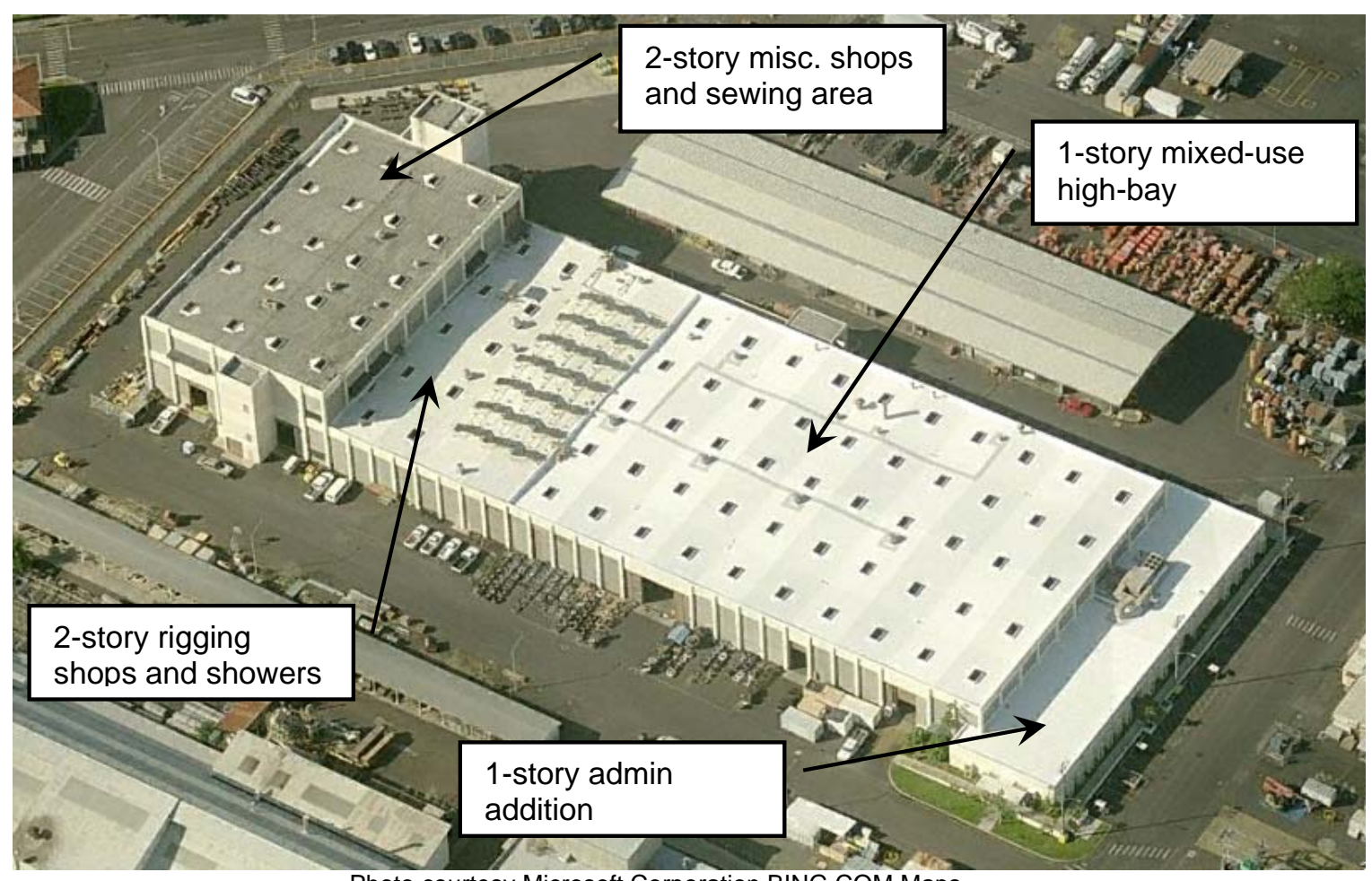

Photo courtesy Microsoft Corporation BING.COM Maps.

Figure C7. Building 1670 Satellite Imagery 
Appendix D

\section{Conversion to Water-Cooled Chillers for Building Space Cooling}




\section{Appendix D: Conversion to Water-Cooled Chillers for Building Space Cooling}

Water-cooled condensing of cooling equipment refrigerant results in a significant improvement in efficiency compared to air-cooled condensing. This advantage stems from two factors. Condenser water from an evaporative cooling tower is generally cooler than ambient air (except when the relative humidity is very high), and water is a more effective heat transfer fluid than air. The two factors work together to lower the refrigerant condensing temperature, hence improving both theoretical and actual refrigeration cycle efficiency. Combining cooling loads met by multiple smaller cooling units into fewer central units allows additional efficiency gains by using centrifugal compressors, a more efficient technology than alternative compressor types commonly used in smaller cooling equipment. These advantages do come at a price, however. Condensing refrigerant with water requires additional costs associated with a cooling tower, condenser water pumps and piping, and a shell to enclose the water as it passes by the condenser tubing. The condenser pump also represents an additional power consuming device that an air-cooled unit does not have. Finally, the distribution of centrally chilled water incurs pumping and piping costs and pumping energy not required by distributed direct expansion coolers (e.g., window AC and packaged rooftop AC).

For the reasons noted above, water-cooled chillers offer significant performance advantages over air-cooled equipment that must be weighed against their additional capital costs. During the last few decades, space cooling has become much more common in Hawaiian military facilities because internal heating loads (e.g., personal computers and other office equipment) have increased, building designs have become less suitable for natural ventilation, and occupants expect a more comfortable working environment. The paragraphs that follow document the expected costs and energy savings associated with example conversions to water-cooled chillers at Hickam, Pearl, and Smith. Many other similar conversions are possible at these three facilities, but additional analysis was not possible with the assessment resources available. The installations are encouraged to consider additional opportunities for using water-cooled chillers where the economics are justified.

\section{Hickam AFB}

Buildings 2130, 2131, and 2133 are currently served by a small central cooling plant comprised of two air-cooled chillers. The proposed retrofit would replace the existing air-cooled chillers with two water-cooled chillers, a cooling tower, and condenser water pumps and piping. The existing chilled water pumps and piping would not change and the electrical service to the central plant should be adequate for the retrofit.

The peak and annual building cooling loads were estimated with the FEDS model, and the performance of the existing chillers was estimated from manufacturer's specifications for the two units. From this information, the annual kWh and peak kW electrical loads were calculated and then combined with Hickam's electricity rates to calculate the 
current annual electricity costs. The existing system performance and electricity cost figures are presented in Table D1.

Although the FEDS model estimates a peak of only 61 tons for the three buildings, two 40-ton water cooled chillers were assumed for the retrofit to match the existing nameplate capacity of the two air-cooled chillers. In this size range, the water-cooled chillers were assumed to use a rotary screw compressor rated at $0.73 \mathrm{~kW} /$ ton. In addition, the condenser water pump and cooling tower fan would be expected to consume $0.12 \mathrm{~kW} /$ ton for a total cooling plant performance of $0.85 \mathrm{~kW} / \mathrm{ton}$. The annual electricity bill for the water-cooled system was calculated to be $\$ 35,360$ based on these assumptions, resulting in an annual savings of about \$15,000 and a peak electric load reduction of $22 \mathrm{~kW}$.

Table D1. Hickam Buildings 2130, 2131, 2133 Existing System Performance and Electricity Cost

\begin{tabular}{|c|c|c|c|c|c|c|c|}
\hline & $\begin{array}{c}\text { Peak } \\
\text { Load, } \\
\text { Tons }\end{array}$ & $\begin{array}{c}\text { Annual } \\
\text { Load, } \\
\text { Ton- } \\
\text { hours }\end{array}$ & $\begin{array}{c}\text { Annual } \\
\text { Capacity } \\
\text { Factor }\end{array}$ & $\begin{array}{c}\text { Existing } \\
\text { Air } \\
\text { Cooled } \\
\text { kW/ton }\end{array}$ & $\begin{array}{c}\text { Existing } \\
\text { Annual } \\
\text { Electricity } \\
\text { kWh }\end{array}$ & $\begin{array}{c}\text { Existing } \\
\text { Peak } \\
\text { Electricity } \\
\text { kW }\end{array}$ & $\begin{array}{c}\text { Existing } \\
\text { Annual } \\
\text { Electricity } \\
\text { Cost }\end{array}$ \\
\hline 2130 & 18.1 & 73,335 & 0.46 & 1.204 & 88,296 & 21.8 & \\
\hline 2131 & 10.3 & 40,647 & 0.45 & 1.204 & 48,939 & 12.4 & \\
\hline 2133 & 32.7 & 100,092 & 0.35 & 1.204 & 120,511 & 39.3 & \\
\hline Totals & $\mathbf{6 1 . 0}$ & $\mathbf{2 1 4 , 0 7 4}$ & $\mathbf{0 . 4 0}$ & $\mathbf{1 . 2 0 4}$ & $\mathbf{2 5 7 , 7 4 5}$ & $\mathbf{7 3 . 5}$ & $\mathbf{\$ 5 0 , 0 8 7}$ \\
\hline
\end{tabular}

The two new 40-ton water-cooled chillers were estimated to cost $\$ 88,200$ and the cooling tower, condenser pump, and piping an additional \$26,100. These figures include all direct construction costs, but do not include any allowance for design or SIOH costs. Based on the direct cost, the payback period is 8 years. With an additional $16 \%$ for design and $\mathrm{SIOH}$, the payback period rises to 9 years.

\section{Pearl Harbor}

Building 631, the Navy Exchange and Commissary, is currently served by a collection of packaged rooftop direct expansion (DX) AC units. The proposed retrofit would replace the existing DX units with a new chilled water coil (in the existing air-handler units [AHU]), two water-cooled chillers, a cooling tower, condenser water pumps and piping, and chilled water pumps and piping. The new chiller plant was assumed to be sited on the southeast side of the building, next to the Commissary.

The peak and annual building cooling loads were estimated with the FEDS model and the performance of the existing packaged DX units was estimated from the vintage of the existing equipment. From this information, the annual $\mathrm{kWh}$ and peak $\mathrm{kW}$ electrical loads were calculated and then combined with Pearl Harbor's electricity rates to calculate the current annual electricity costs. The existing system performance and electricity cost figures are presented in Table D2. 
Table D2. Pearl Building 631 Existing System Performance and Electricity Cost

\begin{tabular}{|c|c|c|c|c|c|c|c|}
\hline & $\begin{array}{c}\text { Peak } \\
\text { Load, } \\
\text { Tons }\end{array}$ & $\begin{array}{c}\text { Annual } \\
\text { Load, } \\
\text { Ton- } \\
\text { hours }\end{array}$ & $\begin{array}{c}\text { Annual } \\
\text { Capacity } \\
\text { Factor }\end{array}$ & $\begin{array}{c}\text { Existing } \\
\text { Air } \\
\text { Cooled } \\
\mathbf{k W / t o n}\end{array}$ & $\begin{array}{c}\text { Existing } \\
\text { Annual } \\
\text { Electricity } \\
\mathbf{k W h}\end{array}$ & $\begin{array}{c}\text { Existing } \\
\text { Peak } \\
\text { Electricity } \\
\mathbf{k W}\end{array}$ & $\begin{array}{c}\text { Existing } \\
\text { Annual } \\
\text { Electricity } \\
\text { Cost }\end{array}$ \\
\hline $\begin{array}{c}\text { Navy } \\
\text { Exchange } \\
\text { (NEX) }\end{array}$ & 275.1 & 918,580 & 0.38 & 1.2859 & $1,181,180$ & 354 & \\
\hline $\begin{array}{c}\text { NEX Food } \\
\text { Court }\end{array}$ & 125.0 & 342,737 & 0.31 & 1.2859 & 440,717 & 161 & \\
\hline Commissary & 194.4 & 716,633 & 0.42 & 1.2859 & 921,501 & 250 & \\
\hline Totals & 594.5 & $1,977,950$ & 0.38 & 1.2859 & $2,543,446$ & 764 & $\$ 493,300$ \\
\hline
\end{tabular}

In this size range, the water-cooled chillers were assumed to use a centrifugal compressor rated at $0.51 \mathrm{~kW} /$ ton. In addition, the chilled water pumps, condenser water pumps, and cooling tower fan would be expected to consume $0.18 \mathrm{~kW} /$ ton for a total cooling plant performance of $0.69 \mathrm{~kW} / \mathrm{ton}$. The annual electricity bill for the water-cooled system was calculated to be $\$ 264,700$ based on these assumptions, resulting in an annual savings of $\$ 228,600$ and a peak electric load reduction of $354 \mathrm{~kW}$.

A new 600-ton water-cooled chiller plant (chillers, cooling tower, pumps, plant piping, electrical, controls, and structure) was estimated to cost $\$ 656,000$. Chilled water piping running to and from the ground to every rooftop air-handling unit was estimated to cost $\$ 225,000$. The cost of the new chilled water coils was estimated to be $\$ 180,000$. These figures include all direct construction costs, but do not include any allowance for design or SIOH costs. Based on the direct cost, the payback period is 4 years. With an additional $16 \%$ for design and $\mathrm{SIOH}$, the payback period rises to 4.5 years.

\section{Camp Smith}

Buildings 401, 402, 403, and 404 are currently served by window DX AC units. The proposed retrofit would replace the window units with room fan coil units, external chilled water supply and return piping and a central water-cooled chiller plant serving all four buildings. The same plant would also serve Building 20. Because the building already has air-cooled chillers, it also has chilled water piping within the building, but will need chilled water supply and return piping to and from the new central plant. The new chiller plant was assumed to be sited on the West side of Bailey Road, opposite Building 401.

The peak and annual building cooling loads were estimated with the FEDS model, and the performance of the existing window DX AC units and air-cooled chillers were estimated from manufacturer's specifications for the two types of units. From this information, the annual $\mathrm{kWh}$ and peak $\mathrm{kW}$ electrical loads were calculated and then 
combined with Smith's electricity rates to calculate the current annual electricity costs. The existing system performance and electricity cost figures are presented in Table D3.

Table D3. Smith Buildings 401-404, and Building 20 Existing System Performance and Electricity Cost

\begin{tabular}{|c|c|c|c|c|c|c|c|}
\hline & $\begin{array}{c}\text { Peak } \\
\text { Load, } \\
\text { Tons }\end{array}$ & $\begin{array}{c}\text { Annual } \\
\text { Load, } \\
\text { Ton- } \\
\text { hours }\end{array}$ & $\begin{array}{c}\text { Annual } \\
\text { Capacity } \\
\text { Factor }\end{array}$ & $\begin{array}{c}\text { Existing } \\
\text { Air } \\
\text { Cooled } \\
\text { kW/ton }\end{array}$ & $\begin{array}{c}\text { Existing } \\
\text { Annual } \\
\text { Electricity } \\
\text { kWh }\end{array}$ & $\begin{array}{c}\text { Existing } \\
\text { Peak } \\
\text { Electricity } \\
\text { kW }\end{array}$ & $\begin{array}{c}\text { Existing } \\
\text { Annual } \\
\text { Electricity } \\
\text { Cost }\end{array}$ \\
\hline 401 & 65.7 & 147,804 & 0.26 & 1.16 & 171,515 & 76.2 & \\
\hline 402 & 65.7 & 147,804 & 0.26 & 1.16 & 171,515 & 76.2 & \\
\hline 403 & 65.7 & 147,804 & 0.26 & 1.16 & 171,515 & 76.2 & \\
\hline 404 & 65.7 & 147,804 & 0.26 & 1.16 & 171,515 & 76.2 & \\
\hline 20 & & & & & & & \\
\hline Totals & 142.8 & 419,327 & 0.34 & 1.44 & 603,203 & 205.3 & \\
\hline
\end{tabular}

In this size range, the water-cooled chillers were assumed to use a centrifugal compressor rated at $0.57 \mathrm{~kW} /$ ton. In addition, the chilled water pumps, condenser water pumps, and cooling tower fan would be expected to consume $0.18 \mathrm{~kW} /$ ton for a total cooling plant performance of $0.75 \mathrm{~kW} / \mathrm{ton}$. The annual electricity bill for the water-cooled system was calculated to be $\$ 164,200$ based on these assumptions, resulting in an annual savings of $\$ 111,300$ and a peak electric load reduction of $206 \mathrm{~kW}$.

A new 400-ton water-cooled chiller plant (chillers, cooling tower, pumps, plant piping, electrical, controls, and structure) was estimated to cost $\$ 520,000$. Chilled water piping that would be mounted on the exterior of Buildings 401-404 was estimated to cost $\$ 85,000$. Chilled water piping running to and from the new central plant to Buildings 401-404 and 20 was estimated to cost $\$ 189,000$. The cost of the new chilled water coils for Buildings 401-404 was estimated to be $\$ 75,000$. These figures include all direct construction costs, but do not include any allowance for design or SIOH costs. Based on the direct cost, the payback period is 8 years. With an additional $16 \%$ for design and $\mathrm{SIOH}$, the payback period rises to 9 years.

Before implementing this project, Camp Smith should consider other possible means of serving these five buildings with water-cooled chillers. An expansion of the chilled water plant serving Building 700 may offer some economies over the new plant proposed here, but the chilled water distribution piping would be longer. Integration with a new chilled water plant serving the eventual replacement of the Old Hospital Complex would probably be ideal if the complex is going to be replaced relatively soon. 


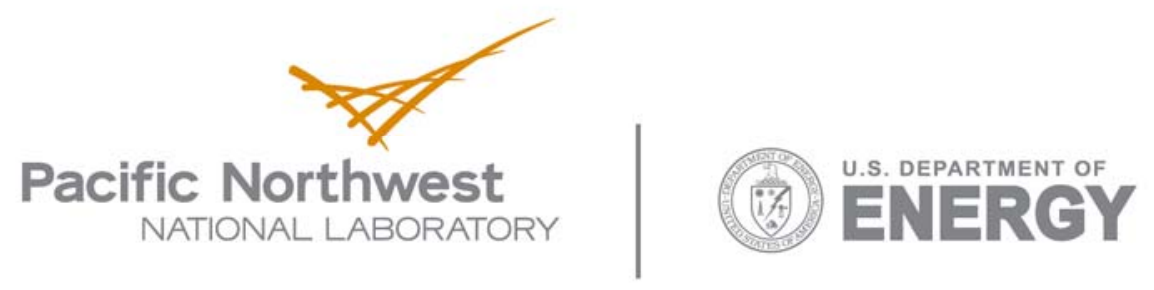

902 Battelle Boulevard

P.O. Box 999

Richland, WA 99352

1-888-375-PNNL (7665)

www.pnl.gov 